\title{
Problem-based Learning
} 2nd (Revised) Edition

Frank Forsythe, University of Ulster

\section{Preface to the Revised Edition}

This revised chapter incorporates numerous enhancements to the original chapter published in 2002.

There are now more examples of how PBL has been used to teach undergraduate economics within a UK context, accessible via the Economics Network website, www.economicsnetwork. ac.uk, and which are listed in Section 6, "Where Next", of this revised chapter. These applications offer potential users of PBL an excellent information source on how the basic PBL concept can be modified to suit particular learning environments. An Appendix has been added containing 4 exemplars of PBL tasks that have been used successfully on a first-year economics module at the University of Ulster. These exemplars reinforce the general principles of PBL design outlined in Section 3, "Designing Problems/Tasks"; an updated "UK Housing Market" exemplar has been retained in Section 3. Section 2 has been extended to highlight some of the recent PBL innovations introduced on economics modules at the University of Ulster.

The original chapter attracted positive comments, for example:

"This chapter is self-contained in that it provides all the information one needs to implement $P B L$, including the preliminary information that should be given to students, how to set up a successful PBL environment and designing PBL tasks. Group work is very important in teaching Economics. It can be used in various forms in seminars, in Problem Based Learning, in Simulations, Games and Role play, in Case Studies, in Cooperative Learning."

Higher Education Academy, June 2002.

"This is a set of guides to inform and improve the practices of university teachers of economics; however, it is interesting and informative for teachers in all curriculum areas."

University of Leicester, "Employment skills within an accessible curriculum".

See http://www.le.ac.uk/ssds/esac/employability_problemsolving.html

It is hoped that the revised chapter remains a useful learning resource for anyone contemplating a PBL approach to teaching. 


\section{Contents}

Preface to the 2nd Edition

1 Introduction 3

1.1 The changing learning and teaching environment 3

1.2 Limitations of the traditional lecture-seminar format 3

1.3 How to use this chapter 4

2 What is problem-based learning? $\quad 4$

2.1 Key features of PBL 4

$\begin{array}{lll}2.2 & \text { Arguments for the use of PBL }\end{array}$

2.3 Recent PBL innovations at the University of Ulster 9

3 Designing problems/tasks 11

3.1 Four steps in designing a task 11

4 Assessing the response to a task 16

$\begin{array}{lll}4.1 & \text { Formative assessment } & 16\end{array}$

$\begin{array}{lll}4.2 & \text { Summative assessment } & 16\end{array}$

5 Designing a PBL environment 17

$\begin{array}{lll}5.1 & \text { Preparing students and staff } & 17\end{array}$

$\begin{array}{llr}5.2 & \text { Setting up a partial PBL environment } & 18\end{array}$

$\begin{array}{lll}5.3 & \text { Setting up a full-format PBL environment } & 21\end{array}$

6 Where next? $\quad 25$

$\begin{array}{llr}6.1 & \text { Websites } & 25\end{array}$

$\begin{array}{lr}\text { Notes } & 27\end{array}$

$\begin{array}{ll}\text { References } & 28\end{array}$

Appendix 1

See associated pdf file 


\section{Introduction}

\subsection{The changing learning and teaching environment}

In many UK universities the learning and teaching environment is changing. In the context of economics, the teaching environment is more complex and diverse than formerly. Curriculum design is now more flexible to accommodate wider student choice. Consequently, economics is often taught within joint or multidisciplinary programmes, with many 'non-specialist' students taking economics for one year or one semester only' ${ }^{1}$. This poses problems for the economics teacher who must confront learners who exhibit varying degrees of commitment to, and aptitude for, the subject. In addition, many students of economics, including those specialising in the subject at single or joint honours level, experience difficulty with the method of economics, particularly in relating abstract concepts, diagrams and models to real-world economic issues and problems.

More generally, teacher-student contact time is also diminishing, making it even more imperative that students develop independent learning skills to ensure that non-contact hours are utilised effectively. Diminished contact time also places additional responsibility on teachers to ensure they adopt appropriate teaching and learning strategies that meet the learning needs of students. Changing attitudes in respect of the role of universities mean that student learning needs are no longer measured in terms of subject-specific skills alone, but encompass a broad range of general skills that enhance the employability of graduates. Pressure on universities to meet these extended learning needs is now formalised through the QAA monitoring procedure with its emphasis on skills development within the programme of study.

Concern about teaching quality is also likely to come from students themselves. With the rising personal cost of university education, one can expect students to insist on a quality learning environment that meets their preferences rather than passively accepting whatever is provided.

\subsection{Limitations of the traditional lecture-seminar format}

My own experience of lecturing undergraduate economics over many years has made me aware that the traditional lecture-seminar format (TLS)2 is not suited to all students. With lectures, the emphasis is on giving information rather than learning - lectures represent what teachers do and not necessarily what students need. Although most lecturers can 'talk' a good syllabus, the real teaching challenge is to ensure that most students are not lost in the process.

Many students lack the confidence (or lack the interest in the case of multidisciplinary and 'nonspecialist' students) to participate effectively in seminars, with the inevitable result that seminar discussions tend to peter out after a relatively brief period. In these circumstances, it is all too easy for the traditionally organised seminar to fall far short of the ideal, in which there is healthy teacher-student and student-student interaction, and come dangerously close to being a teacherdominated environment in which students are spoon-fed. The learning environment becomes a struggle for both teacher (students will not talk) and students (classes are boring).

Students who, for whatever reason, are content to adopt a passive rather than an active role in the learning process are difficult to motivate within a TLS environment. Such a regime may do little to develop confidence and independent learning skills in students who need help in these respects, or to stimulate those who become disinterested. Indeed, the traditional lecture-seminar format can actually alienate such students from the learning process rather than embracing them within it. ${ }^{3}$ 


\subsection{How to use this chapter}

Readers who are familiar with PBL may go directly to the 'design' issues examined in sections 3 and 5, and the 4 exemplars in the Appendix. The PBL structures depicted in section 5 do not need to be implemented in full and can be easily modified to suit the specific learning environment. They are designed to give the reader flexibility and choice in how PBL is introduced into the curriculum. This chapter is self-contained in that it provides all the information one needs to implement PBL, including the preliminary information that should be given to students, how to set up a successful PBL environment and designing PBL tasks. The 'Top Tips' included are based on the author's experience of PBL over a number of years. If new to PBL, it is probably a good idea to try one task only in the first instance. A limited pilot-run will allow you to evaluate the PBL experience from both student and teacher perspectives before undertaking what may be significant changes to your teaching methods second time round.

\section{What is problem-based learning?}

\subsection{Key features of PBL}

PBL involves learning through tackling problems. Although the problems, or tasks, may not always have a 'solution', PBL nevertheless provides a rich learning environment in which students identify what needs to be studied and learnt from examining the problems confronted (Gibbs, 1992). The problems are used as a tool to achieve both the required knowledge base and the skills to 'solve' them (Barrows, 1986). The basis of PBL is that students learn by doing. It is a student-centred system whereby students, working within small groups, generate the information necessary to respond to, or solve, a specific problem or task. One attractive feature of PBL in my experience is that it helps develop in students both subject-specific and transferable skills (Figure 1).

Subject-specific skills are developed directly through problem design, while transferable skills are developed indirectly via the PBL process itself.

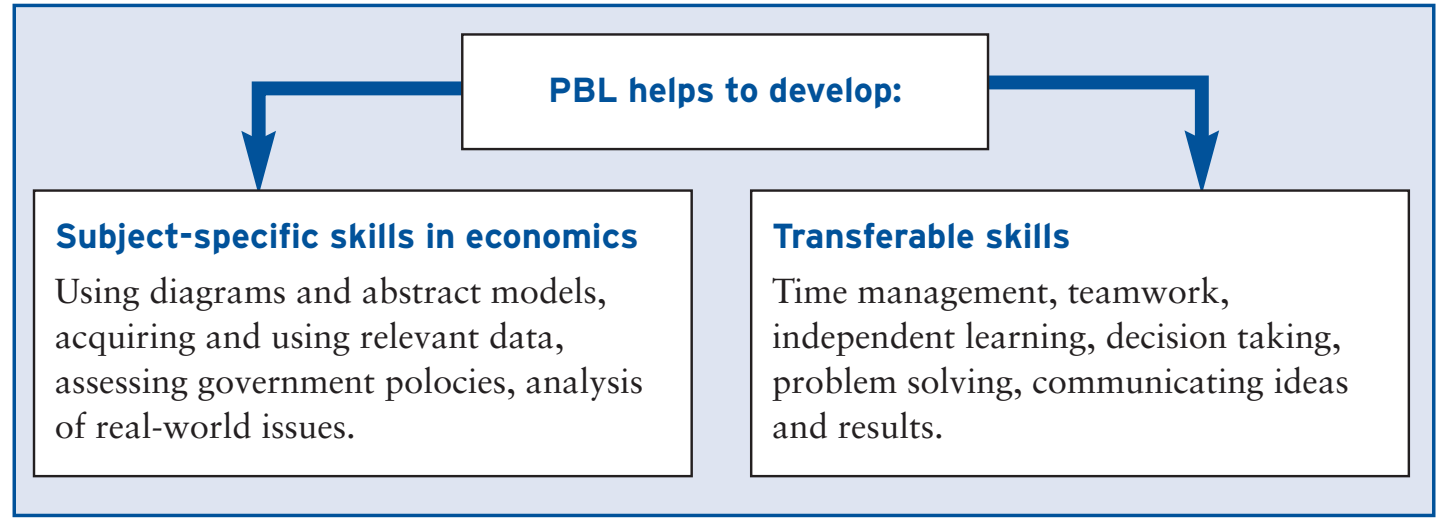

Figure 1 Problem-based learning and skill development 
A PBL environment will normally incorporate the elements depicted in Figure 2. This cycle is repeated for each task. When implementing a PBL environment, one may adopt a 'partial' or 'full-format' model (see section 5 for further details). ${ }^{4}$ In a 'partial' PBL environment, formal lectures are retained and PBL is used to organise the weekly tutorial sessions in support of lectures. In a 'full-format' PBL environment, there are no lectures and the learning environment is driven entirely by PBL methodology.

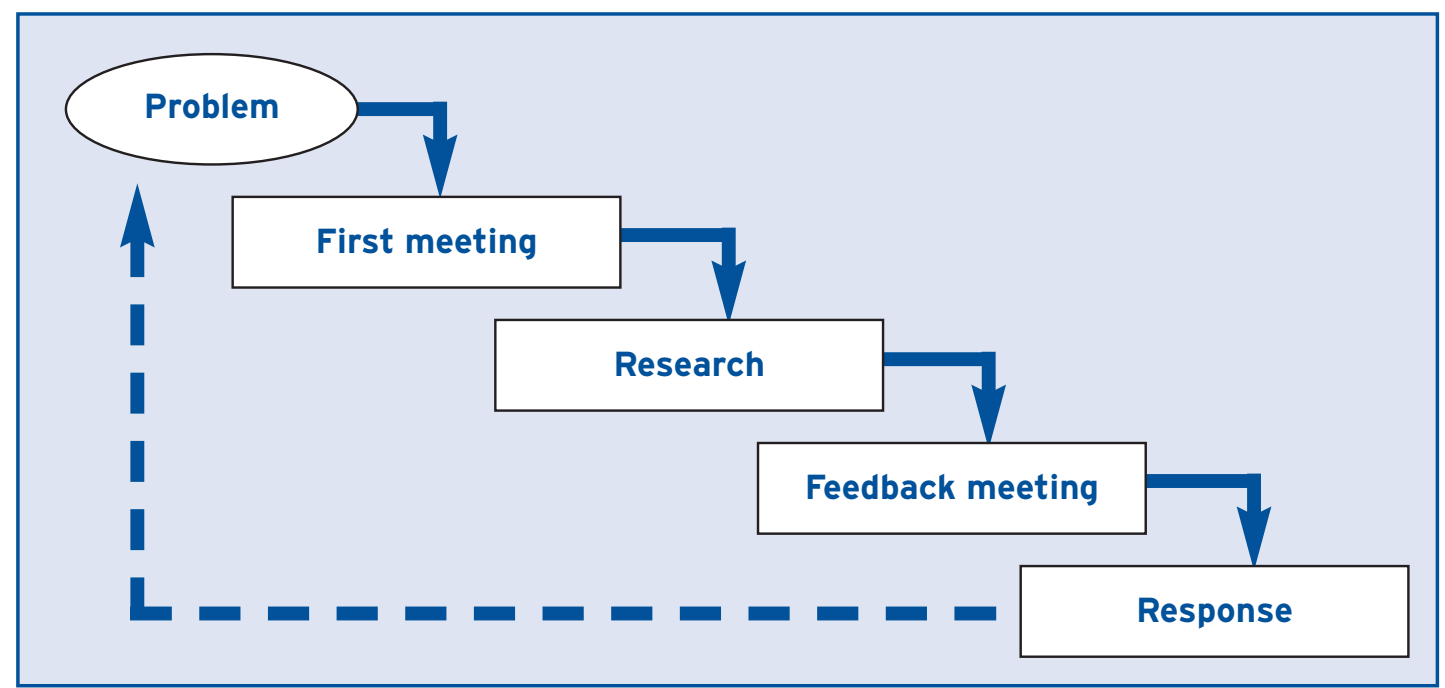

Figure 2 The PBL process

\section{The problem/task}

When designing tasks, the aim is to make students primarily responsible for acquiring and assimilating the information necessary to solve them. In a PBL environment the teacher relinquishes the role of 'expert' and assumes the role of facilitator' ${ }^{5}$. Student learners must adapt to a learning environment in which there is no 'expert' information source. The teacher designs tasks so as to develop the learning outcomes appropriate to the target learner group. I normally design tasks that incorporate data acquisition, model manipulation and evaluative components (the latter may relate to a particular public policy issue, theoretical model or literature review). In this way, the tasks 'drive' students to encounter (and struggle with) subject-specific concepts and issues (Thomas, 2000). The design of PBL tasks for economics students, along with examples, is discussed in section 3.

\section{First meeting}

Students are organised within small groups that work independently from other groups throughout the teaching term. Since I usually design tasks that comprise different components, I use groups comprising 6-8 members. During the first meeting the PBL group discusses the problem for the first time. The meeting is structured to incorporate the following features based upon the 'seven-jump' procedure for handling tasks within PBL groups (Bouhuijs and Gijselaers, 1993; see also the guidelines given to students in relation to the UK housing task illustrated in section 3):

- Initial discussion to ascertain 'first-impression' views of the problem.

- Brainstorming session to identify relevant issues and essential information required to 'solve' or respond to the problem. 
- Identification of specific study tasks (library research, etc.) to be undertaken by group members before the 'feedback' meeting.

- Allocation of study tasks to individual group members (the number of students working on a particular study task will also be determined at this stage).

- For each task the team should select a different task leader and 'recorder'. The task leader is responsible for keeping the discussion going and ensuring that all members participate in team discussions. The task recorder has the responsibility of recording the research responsibilities delegated to members during the first meeting and for reading out this information at the start of the feedback meeting. The students are responsible for all decisions arising from the above activities. The facilitator should not interfere with the governance of group procedures.

\section{Research}

Between the first and feedback meetings associated with a particular problem or task, group members undertake the study task allocated to them at the first meeting. This may entail providing a summary and assessment of relevant journal articles, trawling internet sources, acquiring and tabulating relevant statistical information, etc. Sufficient time must be made available between first and feedback meetings to facilitate research. One-week research periods are used at the University of Ulster (see section 5 for suggestions on designing a PBL environment).

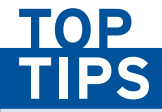

Groups with 6-8 members are easily managed and allow members to work in pairs (if necessary) during the research phase. Groups with fewer members can be successful, particularly with level 2 or 3 students, but the workload on individual members is heavier.

\section{Feedback session}

Members report back the results of their allocated research activity to the group (after the task recorder has reminded the group of individual responsibilities). Using this information, the group formulates an agreed response to the problem.

\section{Group's response}

This can take various forms. It may be a formal presentation using OHP facilities or a written report. The facilitator requires some form of response so that formative feedback can be provided. Assessment may also be summative, in that the response is graded and contributes to overall assessment for the module. Issues and suggestions concerning the assessment of student responses to PBL tasks are considered in section 4.

\subsection{Arguments for the use of PBL}

\section{Research findings relating to PBL}

The use of PBL as a teaching method originated within a medical and health-care context during the 1960s. Although it is now implemented across a wide range of disciplines, PBL research literature is still dominated by medical-based applications. For an assessment of PBL, particularly when compared with conventional lecture-based teaching, see the extensive literature reviews undertaken by Albanese and Mitchell (1993), Vernon and Blake (1993) and Dochy et al. (2003).

Relative to conventional lecture-based methods in which information is transferred from teacher to student, the research literature suggests that: 
- PBL fosters a deeper approach to learning (see also Gibbs, 1992).

- PBL promotes more versatile studying methods and PBL students are more likely to use the library and library resources to study.

- PBL develops greater knowledge retention and recall skills.

- PBL students tend to exhibit stronger knowledge application skills (according to Dochy et al. (2003), this is a very strong and robust result to emerge from the literature).

- From a teacher perspective, PBL appears to be a very satisfying method of teaching.

When comparing the relative performance of two student cohorts studying introductory macroeconomics under conventional lecture-based and PBL methods, van den Bosch et al. (2004) also found that the PBL students exhibited better knowledge application skills than the conventionally taught cohort. According to these authors, PBL promotes a structuring and elaboration of knowledge that develops a more accessible knowledge base.

In terms of the relative knowledge coverage acquired through PBL and conventional lecturebased teaching (as distinct from the application of knowledge to real-world situations), the literature suggests rather mixed results that appear to depend upon the scope of PBL implementation. Based on their literature review, which included only one non-medical research paper, Dochy et al. (2003) found that if the whole curriculum is PBL based, then it is likely that conventionally trained students will have covered, or have been introduced to, more knowledge and facts than PBL-trained students. This, of course, must be weighed against the possibility that conventionally trained students may be less able to retain and apply their wider knowledge base relative to PBL students. The possible differential in knowledge coverage between lecturebased and PBL teaching methods becomes negligible when PBL forms only part of the curriculum.

Finally, one aspect of PBL that requires further study is the possibility that PBL students become too dependent on a small-group environment (Albanese and Mitchell, 1993). PBL students may lack the confidence and the skills to work alone in solving/tackling problems. Clearly any negative effect of excessive reliance on small-group activity will also depend on the scope of PBL implementation within the curriculum. This may also be an issue that is more relevant within a medical rather than an economics or business context.

\section{The PBL experience at the University of Ulster}

The comments below are based upon my own experiences of introducing PBL within a TLSdominated curriculum to teach economics at the University of Ulster in a variety of teaching contexts that has included full-time/part-time students, specialist economics/non-specialist students and first/final-year students. Many of the experiences noted below are consistent with the discussion provided in Gibbs (1992) on how PBL can help develop a deep approach to learning.

Teacher perspective. Students are normally expected to spend additional self-study time for each contact hour with the teacher. At Ulster, for example, 25 per cent of total designated module hours are 'contact' hours during which students meet teachers. Under the more traditional lecture-seminar format, students who are unable to manage the remaining 75 per cent noncontact time, perhaps due to weak independent learning skills, may waste excessive non-contact time before the teacher becomes aware that a student is having difficulty with the module. A key advantage of PBL is that it can help students manage 'non-contact' hours more effectively, since it is during these hours that PBL students are required to generate information for the group within a given time-scale (one week at Ulster). The PBL tasks designed by the teacher determine the learning activities undertaken by students during non-contact hours. This helps to reduce wastage of non-contact hours.

Another key advantage of PBL is that students are required to communicate and discuss the 
subject with other students on a regular basis. This feature of PBL, which requires students to 'talk economics' throughout the teaching term, is particularly attractive when, as at Ulster, one is faced with a student culture that tends to adopt a passive, non-communicative stance under more traditional seminar formats. Such students, many of whom lack the confidence to participate in a teacher-led environment, prefer the teacher to do all the talking and invariably, after an initial struggle, this tends to be the outcome in a conventional seminar format. In this context it is interesting to note that according to the latest available statistics (HESA, 2009) 46.5 per cent of the intake of full-time undergraduates to the University of Ulster fall within the four lowest NS-SEC socioeconomic groups (the UK average is 29.5 per cent). This characteristic of the student population was also highlighted in the QAA Subject Review Report for Economics at Ulster (QAA, approved March 2001, para. 23), and may help to explain the passive stance taken by many students at Ulster within a conventional lecture-seminar environment.

Well-designed PBL tasks also encourage students to become 'information-seekers', undertaking library research and accessing varied information sources - texts, journals, the internet and key statistical sources (i.e. education, health, labour market statistics, etc). This not only helps to develop important information-seeking skills in students, but also encourages greater diversity in student responses to economic issues compared to what may be expected when the teacher is the primary information source.

When PBL is used in 'full format', as described in section 5 (there are no formal lectures), students are obliged to respond to a number of tasks that encompass the full syllabus. Students cannot choose to specialise in the first few topics for examination purposes (and ignore the rest), since PBL requires them to continue working and generating information over all topics. One of the reasons why PBL imposes a severe work regime on students is that it encourages a fuller coverage of the syllabus than the TLS format. ${ }^{6}$

Finally (and according to students themselves), there are externalities associated with PBL. The independent learning, research and time-management skills that are developed within a PBLbased module help students study more effectively in other, non-PBL modules. This suggests that the sooner students experience PBL methods within the curriculum, the greater will be the potential 'externality' effect elsewhere - in other words, some PBL within the curriculum is better than none.

Student perspective. Every student introduced to PBL at the University of Ulster has an opportunity to comment upon his or her PBL experience. A sample of these comments is included in section 5 (where they are discussed in the context of the particular PBL environment encountered).

PBL requires students to work within strict time limits. There is also the additional responsibility of having to contribute to team effort. In the sample of student comments included in section 5, students emphasise the benefits that result from the shared workload and the exchange of ideas that are typical features of PBL. Despite the constant pressure of work, a significant majority of students indicated that their PBL experience was positive rather than negative. Students who disliked PBL cited two reasons - the high workload and a preference for lectures in which the teacher is a primary source of information. ${ }^{7}$

\section{The bottom line: is PBL worth the effort?}

Establishing a successful PBL environment is hard work, requiring written documentation for students, preparation of facilitators, design of suitable PBL tasks, monitoring and assessment of group activities and, very likely, having to manage resources (room layout, for example) that are not designed for group activities.

PBL can also be stressful for both teacher and students, particularly when it is introduced to 
final-year students who are accustomed to a TLS-dominated environment. In these circumstances, teachers must have confidence and belief in what they are trying to achieve if they are to coax the students along. It is at this point one realises that lecturing is a much easier alternative.

Despite the hard work and occasional periods of tension, I continue to use PBL. As a teacher it is a privilege to witness a dynamic group of students working on their own initiative, fired with enthusiasm, striving to solve an economics-related problem. Such groups become extremely efficient at organising the learning environment, arranging additional meetings during noncontact periods and exchanging information via summary reports, photocopies, e-mail and fax (in the case of part-time students). This is active student learning at its best and the effort required to achieve it is worthwhile.

\subsection{Recent PBL innovations at the University of Ulster}

The following innovations have been very successful at Ulster, and are worth serious consideration for anyone contemplating introducing PBL.

\section{(1) Use of final year economics undergraduates to facilitate first year economics PBL groups}

Funding from the Economics Network Learning and Teaching Development Project scheme during 2006-07 permitted the use of final year economics students as PBL group facilitators on the first year microeconomics programme. Depicted below are the views of two final year facilitators, written during the final week of term prior to sitting their own examinations for the BSc (Econ). The facilitators took the same module 4 years previously under a traditional lectureseminar format, and had the same teacher as the current first year students under a PBL format. They were, therefore, ideally placed to comment upon the new PBL regime (see Figure 3).

"The group seemed more willing to take time to explain the basic concepts to individuals who needed help, which in turn seemed to encourage anyone who could not first grasp key concepts to identify problem areas for discussion at the next meeting. It was also surprising to me to note the quality as well as the quantity of work that was completed on time, and this seemed to improve as the weeks progressed. The "positive externalities" included a number of very important aspects of student life, which I felt were often not addressed fully. The development of real, tangible, transferable skills through dialoque, discourse and discussion meant that students better appreciated how to communicate more effectively."

Malcolm Campbell BSc (Econ), facilitator on the first year PBL project, 2006-07

"I liked the emphasis PBL placed on self-study and the penalty system for team members who did not participate. If students did not do their work the group could penalise them and award $0 \%$ if necessary. On the whole I do believe that PBL did make the students more committed to, and interested in, the subject compared to traditional class lectures. The most important thing is the attitude that students take to the new working arrangements - it is important that no individual is allowed to drag a group into inactivity" Paul Keen BSc (Econ), facilitator on the first year PBL project, 2006-07 
"I think this module has definitely enhanced my employment prospects. If I was to write about my experiences in other modules, which were all lectures, it is questionable if they have actually developed my skills. However, with this module I can say that I have improved in many aspects. My teamwork and leadership skills have certainly improved. In most jobs you are inevitably going to be part of a team. This module has certainly given me more confidence in a group situation.

This module has also forced me to be organised, as I have to do the work or else I would be letting my group down. This has instilled good discipline which I hope would carry over to a job.

Another aspect of this module was the presentations. I have done presentations before, but never as involved as those required for this module. At the same time I really enjoyed doing the presentations and was calm and relaxed. I have no doubt that I felt this way because I was comfortable being up with my group members with whom I have formed a bond. Hopefully I can carry over these benefits into employment."

Year 1 student, Microeconomics 1 PBL project, 2006-07

(comments were not edited by the author)

Figure 3 (Continued)

\section{Extending the limits of student self-governance (see Figure 4)}

A primary objective of student-centred learning is to develop confidence in students to make decisions. The measures noted in Figure 4 were introduced for this purpose. If students can be encouraged to take simple decisions on their own initiative, they will eventually develop the confidence to take more difficult decisions.

\section{Extending the limits of student self-governance is achieved in two ways:}

- PBL groups decide WHAT to study by selecting any ' $\mathrm{X}$ ' topics from a total of ' $\mathrm{Y}$ ' topics forming the syllabus (all topics are represented in the final examination). The teacher determines the values of $\mathrm{X}$ and $\mathrm{Y}$.

- PBL groups decide HOW to respond to the PBL task - written report (W) or formal presentation $(\mathrm{P})$. The teacher determines the split between $\mathrm{W}$ and $\mathrm{P}$, which ensures that every PBL group is assessed equally.

For example, suppose there are 6 themes, or topics, forming the syllabus ( $\mathrm{Y}=6)$, all of which are represented in the final examination, and candidates must answer any 3 questions. In the first week of class PBL groups are formed and each group has full information on all the topics in the syllabus including all the learning resources associated with each topic. If PBL groups have to select any 4 topics $(X=4)$, they are covered for the examination. In addition, 2 of the selected topics have to be orally presented $(\mathrm{P}=2)$ and the remaining 2 have to be submitted in the form of a written report $(\mathrm{W}=2)$. This 'enhanced' PBL regime requires PBL groups to begin functioning from the outset, since in the second week each group must (i) select the first topic and (ii) decide whether to respond in the form of W or P.

The above scenario adds an edge to the group format by introducing the need to make important decisions at the beginning of the teaching period. Despite this early pressure to make team decisions, this format is popular with students since it introduces a degree of freedom and flexibility to the learning regime.

Allowing PBL groups to determine X, W and P has proved to be a very successful PBL format on a "labour market" module offered on the final year of the business studies and economics (minor) programmes at the University of Ulster. 


\section{Some Facts}

PBL $v$ LECTURES on the Microeconomics I module, 2007-2008 and 2008-09

Following the 2006-07 PBL mini-project experience, in the 2007-08 academic year the microeconomics I class was split, with half the students following a PBL format, while the remaining half were taught using the traditional lecture-seminar format (TLS). The syllabus content and teacher were the same for both classes. All students sat the same end-of-year examination. In the 2008-09 academic year all students were taught using the TLS format only. Again the syllabus content and teacher were the same over both academic years (and, indeed, the same as the 2006-07 academic year). Prior to 2008-09 all students were registered on the single honours BSc (Economics) programme (S); in 2008-09 students registered on the new BSc (Economics Major) programme (M) took the microeconomics module for the first time. One-third of each year on the economics major programme comprises a non-economics discipline.

\begin{tabular}{|lcccc|}
\hline & $\begin{array}{c}\text { \% Failure } \\
\text { Rate (Exam) }\end{array}$ & $\begin{array}{c}\text { \% Median } \\
\text { Mark (Exam) }\end{array}$ & $\begin{array}{c}\text { \% Failure Rate } \\
\text { (Coursework) }\end{array}$ & $\begin{array}{c}\text { \% Attendance } \\
\text { Rate }\end{array}$ \\
\hline PBL students 2007-08 & 15 & 55 & 8 & 95 \\
\hline TLS students 2007-08 & 53 & 41 & 33 & $<60 *$ \\
\hline TLS (S) students 2008-09 & 18 & 45 & 24 & $74 *$ \\
\hline TLS (M) students 2008-09 & 33 & 43 & 33 & $75^{*}$ \\
\hline * The attendance rates for those failing the examination was $<50 \%$ for all TLS classes. \\
\end{tabular}

\section{Designing problems/tasks}

\subsection{Four steps in designing a task}

This section outlines four key steps in the design of PBL tasks. To illustrate the discussion, a specific task relating to the UK housing market will be considered in detail in this section. The design features outlined in this section are further illustrated by additional exemplars provided in the Appendix.

When designing a task, one should first be aware of the learning activities that students will perform when tackling the task and, secondly, try and visualise (and thus eliminate) possible difficulties that may arise in the process (Bouhuijs and Gijselaers, 1993). In relation to the first consideration, one needs to design tasks that are consistent with the learning outcomes specified for the module and to ensure that the learning outcomes intended are actually realised. Poor problem design may result in actual and intended learning outcomes being different (Dolmans et al., 1993). In respect of the second consideration, a number of difficulties may arise that prevent students from realising intended learning outcomes. One must ensure, for example, that the learning resources required to tackle the task are available - computing facilities, general library resources, access to journal articles, etc. The designer must also ensure that key references are in adequate supply - there is no point in having large numbers of students trying to access one text within a limited time-frame. 


\section{Step 1: Determine the form of the PBL environment}

In a 'partial' PBL environment, in which PBL is used to organise seminars in support of lectures, PBL groups will probably only have an opportunity to meet for 1 hour per week. In a 'fullformat' PBL environment, where PBL replaces lectures, PBL groups will have an opportunity to meet for at least 2 and possibly 3-4 hours per week. Clearly the form of the PBL environment will affect task design in a number of ways, particularly in respect of the learning activities embodied in the tasks and the form of response required of students. Tasks designed for a fullformat PBL environment must span the full syllabus, whereas this is not necessarily the case when designing tasks for a partial environment. In the latter context, one must decide which parts of the syllabus will be reinforced by PBL methods; additionally, one may decide to design tasks that focus on particular learning outcomes, such as data acquisition and/or simple model application. Tasks designed for a full-format environment must relate to all the learning outcomes of the module, and there must also be sufficient time for students to evaluate competing theories, etc. These possibilities and limitations must be taken into account when designing tasks.

\section{Step 2: Focus on target learning outcomes}

The focus for the PBL task should be provided by the subject-specific and transferable outcomes that are being developed. It is useful to start from the outcomes appropriate to the level of the award for which the task is being designed. The target outcomes I use when designing tasks for level 1 students are summarised in Box 1.

To facilitate development of the skills identified in Box 1, tasks normally comprise 3-4 components, encompassing the following elements: (a) diagrammatic manipulation; (b) fact finding; (c) model application; and (d) appraisal. The first three are regarded as being most important at this level. Not all subject-specific skills need be developed by every task. At the introductory level it is also a good idea to have group responses to PBL tasks take the form of presentations (although groups should still provide a written list of sources used).

Some target outcomes for students working at level 3 are presented in Box 2. My level 3 classes are all full-format, with no formal lectures. Once again, tasks normally incorporate 3-4 components.

\section{Box 1 Subject-specific and transferable skills at Level 1}

\section{Subject-specific skills}

- Use of basic diagrams (i.e. models) and economic concepts to explain, describe and analyse real-world situations.

- Use of varied information sources: introductory texts, internet, newspapers, statistical sources and, occasionally, non-technical journal articles and government reports when appropriate (e.g. the occasional online article from Fiscal Studies, Economic and Labour Market Review).

- Use of key facts in support of one's viewpoint.

- Evaluation and appraisal skills - evaluation of a particular situation or public policy issue and ability to give a considered viewpoint or conclusion (though this is given less weighting at level 1 than the other subject-specific outcomes).

\section{Transferable skills}

- As part of a team provide, as required, either a formal verbal presentation of the team's response to the task using OHP facilities or a brief written summary. A written listing of all sources accessed must be included in both cases. 


\section{Box 2 Subject-specific and transferable skills for a final honours module}

\section{Subject-specific skills}

- Use of relevant statistical sources, competence in presenting statistical information and an awareness of the limitations of statistical sources used.

- Competence in the use and evaluation of economic models.

- Evaluation of relevant journal articles in support of one's viewpoint.

- Evaluation and appraisal of economic analysis and public policy.

Transferable skills

- PBL groups will provide, as required, either a formal presentation of the team's response to the task, or a written report. Full referencing of all sources accessed must be included in both cases.

- In respect of presentations, teams will demonstrate effective presentational skills using appropriate resources within the time allocated

\section{Step 3: Determine the learning activities associated with the task}

Table 1 illustrates how the task is related to the chosen target outcomes. This particular task was designed for level 1 students within a partial PBL environment in which PBL was used to organise seminars in support of formal lectures. The task requires students to apply an economic model (supply and demand analysis) to a real-world situation (the UK housing market). It also requires students to undertake information-seeking activities and to share ideas and experiences with peers. Although the basic supply and demand model is introduced during lectures, no reference to the housing market or the related information sources is made during lectures. Data on the UK housing market are available from a wide range of sources, many of which can be accessed via the Bized website. ${ }^{8}$ Tasks can be tailored to accommodate non-specialist students. In the case of law students taking introductory economics, for example, one can design tasks that relate economics to the issue of soft-drug legalisation, discrimination and gender earnings differentials.

Table 1 Designing a PBL task: the UK housing market

\begin{tabular}{|c|c|}
\hline Task components (content) & Skills developed (purpose) \\
\hline 1. Provide regional data for UK house prices & $\begin{array}{l}\text { (Professional/ transferable) } \\
\text { Data acquisition (Web and media-based) }\end{array}$ \\
\hline 2. Model (diagrammatic) manipulation & $\begin{array}{l}\text { (Subject-specific/intellectual) } \\
\text { Diagrammatic exercises using basic supply and } \\
\text { demand model }\end{array}$ \\
\hline 3. Explain regional variations in UK house prices & $\begin{array}{l}\text { (Subject-specificlintellectual) } \\
\text { Application of basic supply and demand analysis }\end{array}$ \\
\hline $\begin{array}{l}\text { 4. Consider market differences between } \\
\text { owner-occupier and private-rented } \\
\text { housing sectors }\end{array}$ & $\begin{array}{l}\text { (Subject-specific) } \\
\text { Extension of basic concepts to an assessment of } \\
\text { a related situation }\end{array}$ \\
\hline $\begin{array}{l}\text { 5. Group delegation of study tasks; collection, } \\
\text { synthesis and presentation of group response } \\
\text { to set task }\end{array}$ & $\begin{array}{l}\text { (Transferable) } \\
\text { Team skills, independent learning, } \\
\text { presentation skills }\end{array}$ \\
\hline
\end{tabular}




\section{Step 4: Presenting the task to students}

Provide all students with a written copy of the task, presented in a format that is helpful to them. The example shown in Figure 5, which is in the format that students receive at the University of Ulster, includes four sections:

- statement of the tasks;

- guidance for the group leader;

- suggested sources of information;

- anticipated learning outcomes.
TOP

TIPS

Make the last task more demanding than earlier tasks and use it as a 'tester' to gauge how well PBL has worked in terms of developing subject-specific and transferable skills.

Key concepts (supply, demand) are highlighted in the task instructions to draw students' attention to the theory they are expected to investigate. At the start of the teaching period, each student is provided with a PBL handbook containing all the tasks for the module (all presented in the same format as Figure 5). Thus each team member has a personal copy of these instructions before their group meeting. The times allocated within each phase of the PBL first session make it more likely that the process is completed within the available time. In this example, first- meeting sessions are restricted to 40 minutes to facilitate the formal presentations that are featured in the partial PBL format outlined in section 5; under the full-format mode, all meetings are of 55 minutes duration (see section 5 for further details).

In my experience it is helpful to provide students with the general guidance depicted in Figure 5, as this is one way of ensuring that actual and intended learning outcomes coincide; it also ensures that the self-directed learning effort by students is channelled in the right direction (Bouhuijs and Gijselaers,

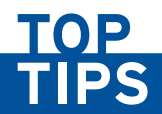

In this task students are provided with specific online articles relating to the UK housing market. This is highly recommended in the first $\mathrm{PBL}$ task. In later tasks students are expected to incorporate their own online sources.

\section{TASK 1 UK HOUSING MARKET}

(A) List four factors that are likely to cause the market supply of UK owner-occupied housing to shift and four factors that are likely to cause the market demand for UK owner-occupied housing to shift.

(B) Using supply and demand diagrams, illustrate how each of the factors listed in (A) are likely to affect UK owner-occupied house prices.

(C) Explain (i) why there are regional variations in UK house prices (provide regional house price statistics in support of your answer) and (ii) the fall in UK house prices since $2007 \mathrm{Q} 3$.

(D) Identify, giving reasons, the factors listed in (A) that are also likely to influence the price of UK private-rented accommodation.

(E) Comment briefly on the factors affecting the provision of social housing in the UK.

\section{Notes for task leader}

1 Appoint a 'Recorder' for the session, and ensure everyone has pen and paper ready to make notes.

2 'Brainstorm' session during which group members discuss ideas (given spontaneously) as to what information they feel is required to provide an adequate response to the task. 
3 Identify 'learning objectives' (to be noted by Recorder): these relate to concepts/ideas arising in 2 above which the group feels are possibly relevant to providing adequate response, but which require additional research time fully to understand/assess relevance. (15 mins)

4 Allocate responsibility for research tasks (to be noted by Recorder). It is via research tasks undertaken between meetings that the group is able to realise the learning objectives identified in 3 above and provide a final, agreed, response to the set task. Emphasise that members must report back their research results to the group at the next meeting.

\section{Hints for leader}

You may need to prompt the group to encourage discussion in the following areas:

Key concepts: Supply, demand, own price, conditions of supply and demand, equilibrium price, market mechanism, supply and demand diagrams.

Essential reading Text, pp. [text references here\}

Internet sources: $\quad$ http://www.bized.co.uk (keywords: UK Housing Market) http://www.timesonline.co.uk/tol/news

http://www.houseweb.co.uk

http://www.nationwide.co.uk

http://www.ft.com/home/uk

You may also find the following helpful (all sourced online using the keywords above):

Housing Market Explained, http://www.housingmarket.org.uk, 18/2/2009.

'Housing shored up by lack of supply', The Financial Times, 15/5/2009.

'Demand for rented homes soars as buyers shun market', The Financial Times,

23/10/2008.

'Brown told to put $£ 6$ bn into social housing', The Financial Times, 23/2/2009.

'House prices rise in good state school catchment areas', The Times, 15/8/2008.

\section{Aims of Task 1}

1 To make students aware of the factors affecting the supply, demand and market prices of UK housing.

2 To encourage students to use supply and demand diagrams.

3 To make students aware of the Internet as an information source.

4 To encourage discussion between students.

5 To encourage group responsibility and sharing of economic ideas and knowledge.

\section{Learning outcomes}

After this task students will:

1 Be aware of the factors affecting the UK housing market.

2 Have manipulated supply and demand diagrams to analyse the UK housing market.

3 Have interacted with peers.

4 Have acquired information for the group and accessed relevant websites and other sources.

Figure 5 Example of instructions for students (Continued) 


\section{Assessing the response to a task}

\subsection{Formative assessment}

All responses by PBL groups must, at the very least, receive formative feedback. If the response has been in written form (a group report, for example) this allows the tutor to make written comments on the report before it is returned to students. In addition, when returning written responses the tutor should also discuss with individual groups the strengths and weaknesses of their response. Thus students benefit from both written and verbal feedback from the tutor. In the case of an OHP presentation, the tutor should take notes during the presentation so as to ensure a worthwhile feedback discussion with the group.

When providing formative feedback, students must be made aware of the factors affecting the quality of their response (both positive and negative) in terms of the learning outcomes associated with the task. This involves both subject-specific and general outcomes. Poor responses can arise due to inadequate team preparation, regardless of the input of individual team members. In the case of weak responses, students require guidance on how to improve their performance in future responses.

\subsection{Summative assessment}

In summative assessment the same mark could be given to each member of a group or individual members could have an opportunity to gain different marks. I adopt the latter approach by combining tutor and peer assessment. See, however, Savin-Baden (2004, A briefing on assessment in $P B L$, listed in the web links provided in Section 6.1) for a summary of the various assessment tools that may be used in a PBL context.

After some trial and error, I have adopted a method of assessment in which the tutor provides an initial total mark for the group response (either a presentation or written report). The maximum mark to be awarded by the tutor is 100 multiplied by the number of group members. A group with six members therefore earns a maximum of 600 . The mark awarded to the group is accompanied by written and oral feedback. If the tutor rates the group's response as worthy of 60 per cent (using assessment criteria contained in the PBL handbook given to students), the group is awarded a total of 360 marks.

The group then has to decide how to allocate the 360 marks amongst the members of the group, with the proviso that no member can be awarded more than 100 marks. If the group decides that all members contributed equally, each member gets the same percentage mark provided by the teacher (60 per cent in this case). Groups can withhold marks from non-contributing members (either totally or partially). This could mean that not all marks are distributed within a difficult group. In this way, working members of the group can still earn good marks, but at the expense of non-working members. This assessment process takes place after each task is completed and each individual's mark is recorded. For summative coursework purposes, each student is given an average mark taken over all the PBL tasks for the module. 
TOP TIPS

If the PBL response is in written form, I advise groups not to indicate which members were responsible for each element of the final report. This allows the teacher to mark objectively without embarrassing particular group members whose contribution may have been weak.

\section{TOP
TIPS}

Ensure that non-working members of the team are severely penalised while working members are fully rewarded.
All group work is open to difficulties created by 'free-riders'. In my experience this has tended to arise with first-year students who have yet to establish appropriate work regimes, with the effect that they regularly missed one of the two meetings per PBL task. This, of course, introduced a disruptive element into the PBL group and it is particularly important that non-workers in a PBL environment are severely penalised whilst workers are fully rewarded. My approach to this problem has been to introduce a number of strict conditions that are clearly stipulated in the module handbook. These conditions are:

- attendance is recorded at every PBL session;

- students missing one of the two sessions per PBL task get no coursework marks for that particular task;

- students who repeatedly fail to contribute to PBL sessions (perhaps missing 4-5 sessions) are withdrawn from their PBL group and will receive no coursework marks for the module as a whole (these students are placed within a 'free-rider' group, to see how 'shirkers' perform within a 'shirker-only' group).

Experience at the University of Ulster suggests that when students are informed about these conditions at the start of their course, poor discipline is largely removed. The problem of free riding has not been apparent with final-year students.

\section{Designing a PBL environment}

\section{TOP \\ TIPS}

Before making serious changes to your teaching approach, have a trial run with PBL by designing and implementing one PBL task only (perhaps having only one of the original tutorial groups complete the task). You can then decide how to proceed after this experience.
This section exemplifies organisational structures for full and partial problem-based learning environments. In each case, the PBL environment is designed for a 12 -week semester, although the structure could be adapted for other circumstances. The assumption in this section is that modules organised on a PBL basis are allocated the same resources as an equivalent module organised on a TLS basis.

\subsection{Preparing students and staff}

For a PBL environment to be successful, staff and students must be aware of what is expected of them and they must be equipped to carry out their designated roles. This section summarises an approach to this preparation.

During the first class students are given a PBL handbook containing the following information:

- A brief description of the PBL process as outlined in Figure 2, and the time available for each stage.

- A description of how group meetings are structured, including the appointment and role of task leaders and recorders.

- The required response to PBL tasks, whether presentations, written reports, etc. The minimum requirements for each type of response are also stipulated. 
- The assessment process, including the assessment criteria used to grade responses.

- Stipulation of every PBL task, including learning outcomes, reading guidelines, hints for task leaders, etc.

- How 'free-riders' are penalised.

Students can also access the PBL handbook using the online facility for the module. E-mail communication between teacher and students is maintained throughout the teaching period.

Before the teaching period begins, it is essential to have a meeting with members of the teaching team who will be acting as facilitators during PBL sessions. Tutors should also be provided with the PBL handbook that is given to students. Difficulties may arise in PBL sessions because tutors have no previous experience of PBL, interfere too much with student governance of the PBL process, or interpret 'facilitating' as 'doing nothing'. It is therefore helpful to have a preliminary meeting with tutors to explain why PBL is being introduced, the potential benefits (and problems) of adopting PBL, the importance of facilitating student self-directed study rather than inhibiting the process, and how PBL sessions will operate. It is essential that regular communication is maintained with tutors throughout the teaching period so that difficulties are identified and dealt with quickly.

Consistency in approach by all tutors is vital. It is wrong, for example, for one tutor to deal with 'free-riders' while another tutor ignores the problem. Hard-working students are being disadvantaged in the latter case and, inevitably, the PBL environment will collapse. When using PBL on first-year modules, careful monitoring of groups throughout the teaching term is imperative. With first-year students there is a greater likelihood of poor self-discipline, which can lead to a breakdown of the group. Safeguarding against this possibility is a crucial role for tutors.

\subsection{Setting up a partial PBL environment}

This section discusses the introduction of PBL to replace the standard seminars in the situation presented in Figure 6. Note that the schedule below can be modified to suit the specific learning environment. The number of tasks can be reduced to any number, 1-4, as required.

Each of the original seminar groups of 15-20 students is split into smaller PBL groups of 6-8 members and each of these groups operates independently from other PBL groups sharing the same seminar room. The size of some PBL groups may be reduced to 4-5 students where the original seminar size is relatively small. Each seminar group (2-3 PBL groups) is allocated one tutor who assumes the role of facilitator. The structure illustrated in Figure 6 assumes that two PBL groups have been formed and that there is one week to research the task between group meetings. Sufficient time for research between first and feedback meetings is imperative.

- two hours of lectures per week (either one two-hour session or two one-hour sessions)

- a 1-hour seminar per week

- one tutor per seminar group

- seminar class size $=15-20$ students

- 12-week teaching period

- assessment comprises coursework and final written examination

Figure 6 Example organisation of a lecture and seminar format 
The partial PBL format depicted in Figure 7 is allocated 1 hour per week (less 5 minutes' wastage due to class changeover, etc). Groups typically have 35 minutes for first-meeting sessions ( 55 minutes in the case of the first task), during which there is an initial 'brainstorming' discussion, identification of learning objectives and delegation of study tasks to be undertaken by group members during non-contact hours. One week later, each group has a 50-55-minute feedback discussion to formulate a response to the task. At the third meeting, 20 minutes are provided during which one group will formally present their response to both the tutor and the other discussion group using OHP facilities. The latter feature provides an opportunity for general class discussion and tutor feedback (formative and possibly summative). When a group does not have to make a verbal presentation, it must provide a written summary of its response to the facilitator for feedback. Providing opportunities for group presentations works well with first-year students. I tend to rely on written responses at other levels (though see Section 2.3 above, "Extending the limits of student self-governance").

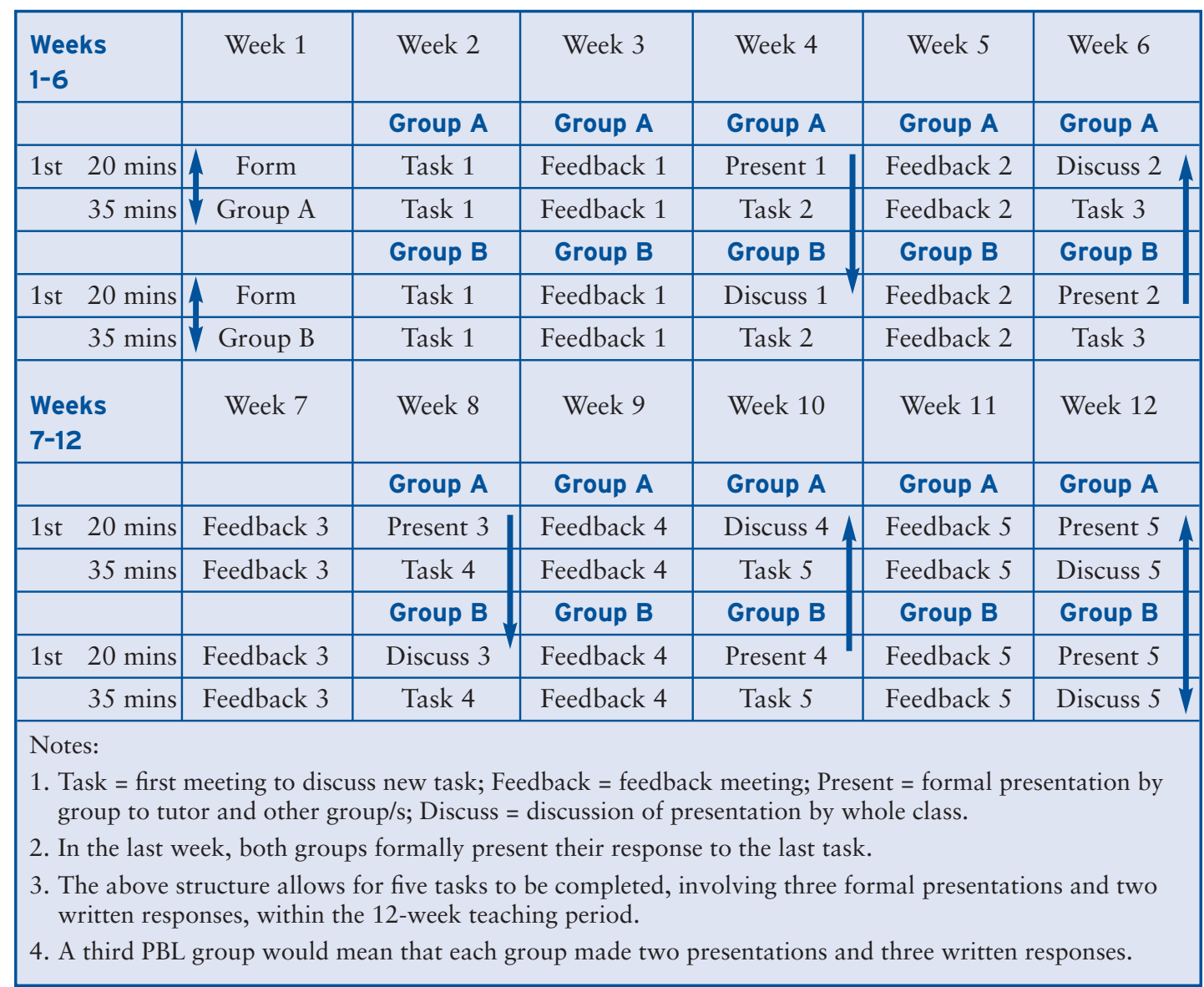

Figure 7 'Partial' PBL environment: 12-week module using PBL structured seminars supporting lectures

The structure illustrated in Figure 7 has been used successfully to teach introductory economics to single and joint honours economics students and non-specialists at the University of Ulster. All students undertaking PBL are asked to complete a questionnaire giving their views on their PBL experiences. A sample of both the positive and negative views and perceptions of Ulster students experiencing the partial system outlined above is provided in Figure 8. 
Key: $\mathrm{E}=\mathrm{BA}$ (Economics); $\mathrm{LE}=\mathrm{BA}(\mathrm{Law}$ and Economics); $\mathrm{EG}=\mathrm{BA}$ (Economics and Government); $\mathrm{PT}$ = part-time non-specialist (mature) student

(1) + Each individual contributed different information. Each student learnt from each other. Only at the beginning was it negative. Students found it difficult to converse because we were new - overall no real negative features.'

(2) + 'I had never encountered economics as a subject before. I was dreading the subject and did not want to do it. However, I'm glad I did and found it interesting. I now see the advantages of having done the module.'

(3) + 'It gave you the opportunity to hear ideas and interpretations on a particular topic from fellow students rather than just from the lecture.'

- 'It was hard at the start to interact with other pupils considering you had just met them.'

(4) + 'Everyone worked well together and everyone got a chance to play a part with the rotation of leader and recorder.'

(5) + 'Everyone participated. Lots of ideas were gained.'

(6) + 'Got to hear other opinions.'

- 'It was embarrassing if you did not fully understand the topic and were therefore unable to contribute.'

(7) + 'It made you research different topics, thereby getting a better insight into the topics.'

- 'If somebody didn't research their allocated task the whole group lost out.' [EG]

(8) + 'A small group meant everyone had a chance to contribute.'

- 'Group leader needs to keep the group focused.'

(9) + 'Group input allowed students to reduce their own personal weakness on a particular topic.'

(10) + 'I was able to relate the theory to real-life situations through the topics discussed and researched.'

- 'There was less opportunity for individuals to ask questions and this could be a problem (not for me as I had done A-level economics).'

(11) + 'It made the subject more interesting. You were actually getting involved and discussing it rather than listening to someone else discussing it.'

(12) + 'You had to concentrate all the time (no hiding in the crowd). You had influence working in a small group; it was easier to ask questions outside of large lecture if you wanted to and got more out of tutorials as a result.'

(13) + 'It helped you think about topics without losing interest as much as in a normal tutorial.'

(14) + 'Raised confidence by working in small group and got to know people I would not talk to otherwise.'

- 'People not turning up and this created problems for others.'

(15) + [Most common positive comments]

'Helped understand topics better by use of real world examples and made to use the internet etc.'

'Work sharing; got to know other people.'

'Hear other people's views.'

'This was interesting team work.'

'Enhanced skills involved with the group.' 


\section{Student perceptions of a partial PBL environment}

All the students were in their first year, taking the same introductory economics module. The part-time students were employed in the public sector and were registered on a public sector studies programme. All students completed the UK housing task illustrated in section 3 above. The dominant feature of the positive comments ( 1 and 3-8, for example) is the synergy that can be generated when students work within small teams in a problem-solving context. The benefits that arise from regular student-student interaction cannot be overestimated, not only in terms of the sharing of ideas, but also in terms of helping to raise confidence (12 and 13) and helping students establish a rapport with their peers - valuable attributes in the case of first-year students. That the experience tends to be enjoyable, relevant and interesting (on the whole), despite the hard work, is suggested by comments 2, 11-13 and 15 .

The role of facilitators is crucial in identifying potential problems before they impact upon the process. Team members who do not participate need to be identified earlier rather than later (negative comments at 7 and 14). Despite the negative perception at (10), facilitators are asked to invite questions/queries from students on a regular basis. In addition, students are encouraged to contact tutors via e-mail whenever necessary. Facilitators must also ensure that task leaders keep the discussion going and that all team members contribute (see the negative comment at 8). Poor facilitating can exert a negative influence on the PBL process.

Overall, however, these comments show that the students did actively participate in the learning environment, sharing ideas and helping peers (or receiving help). All this is in sharp contrast to the TLS environment it replaced. The rationale for introducing partial PBL to teach introductory economics at the University of Ulster is discussed in more detail in Forsythe (2002).

\subsection{Setting up a full-format PBL environment}

Although partial PBL is a valuable experience, the full-format PBL environment is more satisfying for the teacher and students. The reader who has successfully experimented with PBL should aim for the full format. The absence of the lecture removes a constraining feature on the focus and organisation of the problem-based learning environment. PBL is particularly suited to final honours teaching, where the potential for generating focused teamwork is greatly enhanced. Group meetings follow the same procedures as under the partial system, except that groups now meet for 2 hours per week rather than 1 hour. It is also possible to require a more demanding response from students: in the cases described below, students were asked to prepare a written group report of between 1500 and 2000 words in response to each task.

Two examples are discussed in this section, both based on actual teaching experiences with level 3 modules. In both cases, 3 contact hours are provided (giving a 2-hour lecture and a 1-hour seminar under the TLS system). In the first example there are only 15-20 students taking the module, and thus 2-3 PBL groups can be formed. In the second, more demanding example, there are 9-10 PBL groups. The perceptions of students who have experienced a full-format environment are also provided below.

The system depicted in Figure 9 generates an accumulated workload that exerts significant time and work pressure on students - this, one might argue, simulates the real-world working environment. Under this system a much more subtle understanding and development of group dynamics can be developed in students. These are skills that are valued highly by employers. In many instances, students have reported this outcome following job interviews undertaken after completing the module.

In the system illustrated in Figure 9, each PBL group follows the same structure. This organisation assumes that there are seven tasks (this can be varied), a one-week research period and written responses to each task. This seven-task system imposes a hard working regime on 


\begin{tabular}{|c|c|c|c|c|c|c|}
\hline $\begin{array}{l}\text { Weeks } \\
1-6\end{array}$ & Week 1 & Week 2 & Week 3 & Week 4 & Week 5 & Week 6 \\
\hline 1st hour & Form & & Feedback 1 & Feedback 2 & Feedback 3 & Feedback 4 \\
\hline \multirow[t]{6}{*}{ 2nd hour } & groups & Task 1 & Task 2 & Task 3 & Task 4 & Task 5 \\
\hline & & & & S-report 1 & S-report 2 & S-report 3 \\
\hline & & & & & Assess-T1 & Assess-T2 \\
\hline & & & & & & Assess-P1 \\
\hline & & & & & & $\downarrow$ \\
\hline & & & & & & Record 1 \\
\hline $\begin{array}{l}\text { Weeks } \\
7-12\end{array}$ & Week 7 & Week 8 & Week 9 & Week 10 & Week 11 & Week 12 \\
\hline 1st hour & Feedback 5 & Feedback 6 & Feedback 7 & & & \\
\hline \multirow[t]{6}{*}{ 2nd hour } & Task 6 & Task 7 & & & & \\
\hline & S-report 4 & S-report 5 & S-report 6 & S-report 7 & & \\
\hline & Assess-T3 & Assess-T4 & Assess-T5 & Assess-T6 & Assess-T7 & \\
\hline & Assess-P2 & Assess-P3 & Assess-P4 & Assess-P5 & Assess-P6 & Assess-P7 \\
\hline & 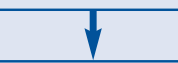 & 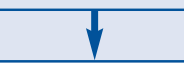 & $\downarrow$ & $\downarrow$ & $\downarrow$ & $\eta$ \\
\hline & Record 2 & Record 3 & Record 4 & Record 5 & Record 6 & Record 7 \\
\hline \multicolumn{7}{|l|}{ Notes: } \\
\hline \multicolumn{7}{|c|}{$\begin{array}{l}\text { 1. The first hour is used for feedback meetings and the second hour is used for the group's first meeting to } \\
\text { discuss a new task. } \\
\text { 2. Task = new task (first PBL meeting); Feedback = second PBL meeting; S-report = submission of } \\
\text { written report; Assess-T = teacher feedback and total assessment marks awarded for group report; } \\
\text { Assess-P = peer-agreed distribution of teacher marks within group; Record = recording of individual } \\
\text { summative marks following Assess-P. } \\
\text { 3. Assess-T, Assess-P and S-report can be provided during the first or second hourly meeting of PBL groups. } \\
\text { 4. If the timetable has provided one 2-hour lecture period, the first and feedback meetings may be back-to- } \\
\text { back over the } 2 \text { hours, or the third 'seminar' hour may be used along with one of the original lecture hours } \\
\text { to separate the two meetings. }\end{array}$} \\
\hline
\end{tabular}

Figure 9 12-week final honours module using full PBL format

students. However, a number of 'escape routes' are possible if it is felt that students are under too much pressure. First, the system illustrated does not use the third hour timetabled each week. This can be used to provide additional time for PBL activities, including longer group discussions or quite separate activities. In my own case this hour is used as a teacher-led weekly 'journal-shop'. Each week one journal article is selected to demonstrate the methodology it uses to address a particular issue in labour economics. Secondly, there are 7-9 unused hours (at the start and end of the teaching period) which can be used for mini-lectures, workshop activity, revision or further PBL time. Finally, the teacher can decide to set only five or six tasks, giving more time to complete each task.

\section{Student perceptions of a full-format PBL environment}

The comments in Figure 10 were provided by final honours students taking an optional module in labour economics. The comments have been grouped according to key aspects associated with small-group activity. It is important to note that students were not prompted to provide comments corresponding to these headings. The comments were only grouped after the views had been received. 
A number of perceptions are dominant. The full-format PBL experience is no easy option and requires hard work throughout the teaching period (this is the main thrust of the negative comments, 39-41 and 45). The synergy generated within final-year PBL groups is a particularly rewarding experience for the teacher as well as for students. The comments under 'group dynamics' (1-9) and elsewhere convey an extremely healthy, relaxed and enjoyable atmosphere, yet the work rate progresses, as evidenced by the comments under 'benefits of PBL' (14-30) and 'skills developed' (31-38). Although the 'free-rider' problem tends not to be an issue with final honours students (13), I was impressed that when it did surface (10-12), team members resolved the issue without involving the facilitator. The externality effect of PBL, whereby non-PBL modules benefit from the skills acquired by students on PBL modules, is also noted (21). It is, of course, important to be aware that some students cannot adjust to a PBL environment, and prefer a conventional lecture-based approach (43).

Overall, the views of final honours students tend to be strongly supportive of the PBL approach to teaching. It is particularly pleasing to have students themselves admit that they have developed key subject-specific and general skills on the module $(31-38,17,20$ and 21, for example). While a teacher may presume that appropriate skill development has occurred, one can never be sure this has been the student experience. Although designing and maintaining a full-format PBL environment is hard work for the teacher, one senses that one is going in the right direction and doing the right thing.

\section{Team dynamics}

(1) 'Everybody was willing to put in a lot of effort and wanted to do well in the set tasks. At the beginning we established a routine of how to do the tasks and it worked very smoothly every week.'

(2) 'Everyone pulled their weight. If people were going to be absent, they let the other team members know and prepared their work in advance.'

(3) 'Everyone was motivated to get as much information as they could for the group. Nobody wanted to let the team down."

(4) 'Everyone in the group participated and each did their part. We all learnt from each other as everyone submitted different ideas and information, and so we were able to cover a lot of ground in each topic.'

(5) 'There was a relaxed attitude, so people felt they could speak out and give an opinion. Everyone was willing to research as none of us knew anything about the topic.'

(6) 'Everyone worked very well together, it proved an enjoyable experience for everyone involved.'

(7) 'Group members could rely on each other and were prepared to meet outside class times to get things done well.'

(8) 'Everyone shared information. There was a high degree of trust.'

(9) 'Everyone exchanged contact numbers and so we had support if needed.'

\section{Coping with free-riders}

(10) 'I don't feel that we had any free-riders. We did have teething problems initially, but we discussed them as a group and were able to improve the way we worked as a team.'

(11) 'We confronted the person involved to try and understand and discover what problems he was facing.'

(12) 'They were confronted and asked to explain themselves. The situation was resolved by listening to their problems and then helping them to overcome these problems.'

(13) 'We didn't have any free-riders.' [This was the response of 92 per cent of PBL students.]

The benefits of PBL

(14) 'It gave me a chance to meet new people. Also to see how different people take different approaches to the one question.'

(15) 'Confidence, shared information, different opinions.' 
(16) 'I learnt where to find various sources of information. I also learnt how to participate in a group and work within a team.'

(17) 'The information gathered was up-to-date. It was easier to digest and remember information obtained this way as opposed to reading lecture notes. The group was able to cover a wider scope when looking for information than one person working alone.'

(18) 'Better than sitting in a lecture. We learnt more because we had to find the information ourselves. We also became much more aware of information sources.'

(19) 'Each team member had different skills to bring to task discussions and I picked up very valuable information from each of them.'

(20) 'Merging individual views into a joint document was an excellent learning process.'

(21) 'The problem-solving skills I developed on this module will help me study my other modules next semester.'

(22) 'I learnt more about the subject researching it myself rather than being lectured.'

(23) 'Apart from the social aspect of meeting new people and having a bit of "craic", it was a very valuable experience working in the group. I am a quiet person and group work made me provide an input to team effect.'

(24) 'I was shown by another group member how to access journals etc. and I experienced a wide range of skills.'

(25) 'It gave me experience in researching data sources. This was an area in which I had little experience. It also helped me develop a professional approach to tasks.'

(26) 'Given a lot of responsibility - introduced me to independent learning.'

(27) 'Group morale was high. Knowledge gained was more extensive and better than lectures.'

(28) 'The fact that the majority of people did the work meant it was easier to learn the material.'

(29) 'It benefited my organisational and interpersonal skills. Also my diplomacy was tested with certain members of the group.'

(30) 'It forced us to do the research ourselves.'

\section{What skills do you believe you developed?}

(31) 'Research methods, communication skills, leadership, selection of quality data from a vast range of data.'

(32) 'The ability to select relevant data and dispose of rest.'

(33) 'Communication, reporting, negotiation, data selection, leadership.'

(34) 'Team working, research methods. I also gained self-confidence with this method.'

(35) 'Time management, meeting deadlines, interpersonal skills.'

(36) 'Delegating, researching, organising and summarising issues (through the written response part of the set task).'

(37) 'More in-depth research skills and applying data and economic models to real-world situations.'

(38) 'I feel that this method of teaching developed my problem-solving skills.'

Negative aspects - not all students like active learning! Also, some students who enjoyed the PBL experience overall had reservations with certain aspects.

(39) 'It put us under a lot of pressure to complete the work on time. I did not enjoy it at all.'

(40) 'Meeting outside of scheduled classes.'

(41) 'Too much hard work every week - the pressure did not subside.'

(42) 'You had to depend on others for vital information, and you have to trust their input to the process.'

(43) 'I would have preferred more lecture-based teaching.'

(44) 'On occasions we all wanted to be leader which led to confusion.'

(45) 'It was quite time consuming. I spent a lot of extra time researching and meeting up with other members of the group outside of class hours.'

Figure 10 Students' evaluations of full-format problem-based learning (Continued) 


\section{Where next?}

\subsection{Websites}

There are thousands of PBL related sites. The focus here has not been to detail its historical development, but to direct readers to useful information sources that will help one decide whether PBL is for them and, if so, how to take the initial 'plunge'. Most of the PBL applications included below provide some sort of 'ad hoc' evaluation, in addition to highlighting some of the practical benefits and problems encountered by practitioners.

The resources listed here provided free access at time of writing. Sites requiring payment for downloading articles have been excluded.

\section{What is PBL?}

Learning Materials in a Problem Based Course. Contains a PBL guide produced by the Department of Materials, Queen Mary College, University of London. Includes information on structuring PBL sessions, assessment and other issues.

http://www.materials.ac.uk/ guides/pbl.asp

Problem Based Learning - Wikipedia. Provides useful web links. http://en.wikipedia.org/wiki/Problem-based_learning

Higher Education Academy Imaginative Curriculum Guide: Problem-based Learning. http://www.heacademy.ac.uk/assets/York/documents/resources/resourcedatabase/id362_ Imaginative_Curriculum_Guide_Problem_Based_Learning.rtf

A Briefing on Assessment in PBL. HEA Generic Centre Assessment Series, No. 13 (2004). http://www.heacademy.ac.uk/resources/detail/id349_A_Briefing_on_Assess

Sharing Ideas and Research in Social Sciences Learning and Teaching: Problem-Based Learning. HEA Subject Centre for Sociology, Anthropology and Politics (C-SAP). http://www.c-sap.bham.ac.uk/resources/project_reports/ShowOverview.asp?id=4

\section{Relevance of PBL for employability skills}

The Skills and Knowledge of the Graduate Economist (2007). Employer survey conducted on behalf of the Royal Economics Society and the Economics Network to identify employer understanding and requirements of economics graduates' skills and knowledge. http://www.economicsnetwork.ac.uk/projects/employability2007full.pdf

Economics students' employability profiles (2005).

http://www.economicsnetwork.ac.uk/themes/EconomicsSEP.doc

Economics Students Survey (2006). Updated regularly. http://www.economicsnetwork.ac.uk/projects/employability2006.htm

Employment Skills within an Accessible Curriculum (ESAC). Student Support and Development Service (SSD), University of Leicester. ESAC is a HEFCE funded project exploring how employability skills can be developed in a way that benefits all students equally (i.e. student disability catered for). http://www.le.ac.uk/ssds/esac/index.html http://www.le.ac.uk/ssds/esac/employability_problemsolving.html 


\section{Using PBL to teach economics}

All available at the HEA Subject Network for Economics.

http://www.economicsnetwork.ac.uk/showcase/approaches.htm

Teaching Structuralist Economics Using Problem Based Learning and Weblogs

Stephen Kinsella, University of Limerick, Ireland (Jan 2008)

Problem Based Learning in final year (year 3) module Economic Growth

Guglielmo Volpe, London Metropolitan University (Oct 2007)

Using Problem Based Learning (PBL) to teach Industrial Economics

John Sedgwick, London Metropolitan University (Jan 2007)

Introducing Problem-Based Learning to a First Year Economics Curriculum

Frank Forsythe, University of Ulster (October 2007)

Includes a number of PBL tasks designed for a first year microeconomics module

Developing a PBL course in Economics: a sceptic's diary (Introduction)

Judith Piggott, Oxford Brookes University (Oct 2002)

Developing a PBL course in Economics: a sceptic's diary (Part 2: Report on Maastrict Visit) Judith Piggott, Oxford Brookes University (Feb 2003)

Developing a PBL course in Economics: a sceptic's diary (Part 3: Implementation) Judith Piggott, Oxford Brookes University (May 2004)

Developing a PBL course in Economics: a sceptic's diary (Part 4: 4 years on)

Judith Piggott, Oxford Brookes University (Aug 2006)

Using Problem Based Learning and a Business Game in Teaching Managerial Economics

Pierre Picard, University of Manchester (Dec 2002)

Using Problem Based Learning (PBL) to Teach Economics

Frank P. Forsythe, University of Ulster at Jordanstown (Oct 2001)

The evolution of PBL in 'Economics for Business' (ECQ450) from 2004 to 2009

Denis McGrath, University of Westminster.

This is PBL on a mega-scale, using the intranet facility to organise and run PBL for large numbers of Year 1 students. A reflective piece that is well worth reading.

http://www.economicsnetwork.ac.uk/events/pbl10510

Promoting Problem-Solving Based Independent Learning in Macroeconomics

David McCausland, University of Aberdeen (April 2001)

Problem Based Learning

Peter Pierpoint, University of Plymouth (Feb 2001)

\section{Other economics applications of PBL}

Making Sense of Economics: Designing Educational Scenarios for problem-Based Learning. Paper presented at conference 'Creativity or Conformity? Building Cultures of Creativity in Higher Education', at the University of Wales Institute, Cardiff in collaboration with the Higher Education Academy, January 2007.

http://www.creativityconference07.org/presented_papers/Arul_Experiencing.doc

Implementing Problem Based Learning in a Science Faculty. University of Western Australia (2008). This application relates to a module in Resource Economics.

http://www.iier.org.au/iier18/pepper.html 


\section{General Sources}

Coventry University / HEA PBL

Use 'PBL' keyword in the 'search the site' facility. This site has a variety of resources, details upcoming events, and has an insightful reserach paper by Savin-Baden and Wilkie.

www.coventry.ac.uk

Project on The Effectiveness of Problem Based Learning (PEPBL)

This site details a current systematic review and evaluation into the efficacy of PBL within the Nursing curriculum.

www.hebes.mdx.ac.uk/teaching/Research/PEPBL

Centre for Instructional Support, University of Colorado

www.uchsc.edu/CIS/PBL.html

University of Maastricht PBL

A founder of the PBL model in Europe, with a wide variety of resources available. www.unimaas.nl/pbl/

Australian PBL Teaching and Research Network, University of Newcastle

A comprehensive PBL bibliography.

www.newcastle.edu.au/services/iesd/learndevelop/problarc/

Health Sciences and Practice

http://www.health.heacademy.ac.uk/sig/problembased/whatispbl

Notes

1 At the University of Ulster, for example, introductory economics is taught on a wide range of programmes, including business studies, accounting, engineering, building, sports studies and health sciences.

2 In a TLS environment, lectures facilitate teacher-led information while seminars provide an opportunity (in theory at least) for teacher-student and student-student interaction.

3 Interestingly, it is suggested in Becker and Watts (1996) and Becker (1997) that teaching methods dominated by traditional 'chalk and talk' lectures with rare use of small-group interactive teaching methods may be a contributing factor in causing the decline in applications for single-discipline economics in the USA.

4 The terms 'partial' and 'full-format' to describe different PBL environments are the author's own. Under 'full-format' PBL there is provision for the occasional mini-lecture if required (see section 5).

5 For an excellent detailed discussion of the role of facilitator, see Woods (1996), ch.2, 'On being a coach/facilitator' at: http://chemeng.mcmaster.ca/pbl/pbl.htm

6 Thus PBL is less likely to generate 'redundant' questions that are avoided by students in the final examination.

7 These results are consistent with those cited by Longuevan (2000) when using PBL to teach economics at University of California, Irvine (at: www.pbl.uci.edu/winter2000/ ss10csurvey.html).

8 After accessing Bized at www.bized.co.uk, select 'learning materials' followed by 'economics'. This site contains useful level 1 material on a range of topics, including market failure, costs and minimum wages. 


\section{References}

Albanese, M. and Mitchell, S. (1993) 'Problem-based learning: a review of literature on its outcomes and implementation issues', Academic Medicine, 68, (1), pp. 52-81.

Barrows, H. (1986) 'A taxonomy of problem-based learning methods', Medical Education, 20, pp. 481-6.

Becker, W. (1997) 'Teaching economics to undergraduates', Journal of Economic Literature, 35, pp. 1347-73.

Becker, W. and Watts, M. (1996) 'Chalk and talk: a national survey on teaching undergraduate economics', American Economic Review, 86, (2), Papers and Proceedings, pp. 448-53.

Bouhuijs, P. and Gijselaers, W. (1993) 'Course construction in problem-based learning', in Bouhuijs, P and Schmidt, H. (1993), Problem-Based Learning as an Educational Strategy, Network Publications, Maastricht, ch. 5.

Cohn, E. and Cohn, S. (1994) 'Graphs and learning in principles of economics', American Economic Review, 84, (2), Papers \& Proceedings, pp. 197-200.

Dochy, F., Segers, M., Van den Bossche, P., and Gijbels, D. (2003) 'Effects of problem-based learning: A meta-analysis', Learning and Instruction, 13, pp. 533-568.

Dolmans, D., Gijselaers, W., Schmidt, H. and van der Meer, S. (1993) 'Content coverage in a problem-based curriculum: studies on the effectiveness of problems', Academic Medicine, 68, (3), pp. 207-213.

Forsythe, F. (2002) 'The role of problem-based learning and information technology in a spoon-fed undergraduate environment', in Johannessen, T., Pedersen, A. and Petersen, K. (eds), Educational Innovation in Economics and Business, 6, Kluwer Academic Publishers, Amsterdam, pp. 147-161.

Gibbs, G. (1992) Improving the Quality of Student Learning, Technical and Educational Services Ltd, Bristol.

HESA. (2009) Table 1a - Participation of under-represented groups in higher education: Young full-time first degree entrants 2007/08, at:

http://www.hesa.ac.uk/index.php?option=com_content\&task=view\&id=1434\&Itemid=141

Longuevan, C. (2000) 'Using PBL to teach economics at University of California, Irvine', at: www.pbl.uci.edu/winter2000/ss10csurvey.html

Thomas, J. (2000) 'A review of research on project-based learning', The Autodesk Foundation, San Rafael, California, at:

https://www.bie.org/files/researchreviewPBL.pdf

Van den Bossche, P., Segers, M., Gijbels, D. and Dochy, F. (2004) 'Effects of problem-based learning in business education: a comparison between a PBL and a conventional approach', in Ottewill, R et al (Eds), Educational Innovation in Economics and Business, Volume VIII, Kluwer Academic Publishers, Dordrecht, Netherlands, pp. 205-227.

Vernon, D. and Blake, R. (1993) 'Does problem-based learning work? A meta-analysis of evaluative research', Academic Medicine, 68, pp. 550-563.

Woods, D. (1996) Problem-based Learning: Helping Your Students Gain the Most from PBL, originally published in 1994 by McMaster University Bookstore, Ontario. Third edition, March 1996, at: http://chemeng.mcmaster.ca/pbl/pbl.htm 


\section{PBL EXEMPLARS FOR A FIRST YEAR ECONOMICS MODULE}

The exemplars provided in this section have been used, either wholly or in part, as PBL tasks in the teaching of first-year economics at the University of Ulster. They are included here as suggestions, or prompts, to help first-time users of PBL to design their own PBL resources to suit their particular learning environment.

\section{Note the following PBL design features:}

- Each exemplar can be used in full, or sub-divided into smaller components if time is limited (i.e. the tasks are flexible)

- The element of variability in the tasks, in terms of:

$\circ$ the required student responses - presentations, written reports, 'university challenge' type quiz

○ the learning resources to be accessed - media articles, websites, reports, data, text, online tutor notes

- The application of theory to real-world situations (i.e. $\underline{\text { realism) }}$

- Each exemplar is supported, in that all supporting information necessary to complete the task is provided:

$\circ$ advice for task leaders

- learning resources stipulated, including all Web links

- learning outcomes stipulated

The above design elements are crucial if PBL is to meet the needs of both students and teachers. Realism and variability in PBL tasks help retain student interest and commitment; flexibility and supportiveness allow tutors to control the learning environment, particularly the pace and direction of student learning. 


\author{
Core Concepts \\ Applications \\ Response Required
}

1(a) From the data you have obtained (see below), choose the GDP measure you think appropriate and calculate the income elasticity of demand for new cars for (i) 1989-1991 (ii) 1994-1998

(b) Explain briefly your choice of GDP measure in (a)

(c) How would you categorise "new cars" from your results in (a) - 'normal' or 'inferior' products?

(d) Using supply \& demand diagrams, illustrate what happened in the UK market for new cars in each of the periods noted in (a). What evidence is there in support of your conclusions for the earlier period from the article available at http://www.iht.com/articles/1991/07/04/ford.php?

(e) With the aid of the article available at the address below identify 4 conditions of demand for new cars: http://cfit.independent.gov.uk/pubs/2000/ebpt/ebptgerman/04.htm

2 "The elasticity was found to be less than 2." Explain why this statement is ambiguous, and make any modification you think necessary to give it economic meaning.

3 Using the publication, Desktop Study into Demand for Dairy Products, Section 2, pp3-12, Provide evidence in support of the view that market forces do not favour farmers.

You should illustrate your answer with supply and demand diagrams. http://www.defra.gov.uk/foodfarm/food/industry/sectors/milk/pdf/agraceasreport.pdf

$4 \quad$ Draw ONE supply and demand diagram that illustrates the general pattern to emerge from the PESTICIDE DATA in Table 1 attached. Explain briefly why you would expect the values depicted in the last column

\section{LEARNING OUTCOMES - AFTER THIS TASK STUDENTS WILL BE ABLE TO:}

- Understand the influence of market forces on product prices.

- Define and calculate different measures of elasticity.

- Assess how the impact of changing market forces depends upon market elasticities

- Understand the relevance of elasticity for government policy and firms

- Assess the relevance of elasticity for farm incomes

- Illustrate and assess the impact of a commodity tax on market outcomes

- Understand how environmental and other public policy objectives can be attained via the use of commodity taxes 


\section{EXEMPLAR 1 (contd)}

\section{Notes for Task Leader:}

You may need to prompt the group to encourage discussion in the following areas:

Key concepts: $\quad$ Elasticity of demand \& supply (price elasticity of demand \& supply, income and cross elasticity of demand); related markets; price elasticity and sales revenue; the relevance of time for price elasticity of supply; the rationale for protecting farm incomes; supply and demand representation of a commodity tax; the incidence of a commodity tax.

\section{Learning Resources}

TEXT Demand elasticities Supply elasticities Elasticity and farm incomes Sales taxes and elasticity

INTRANET
TEXT REFERENCE (essential)
TEXT REFERENCE (essential)
TEXT REFERENCE (essential)
TEXT REFERENCE (essential)

Lecturer's online presentation (optional) Lecturer's online presentation (optional) Lecturer's online presentation (optional)

\section{INTERNET}

"Ford Lands Price Blow in U.K. Car War", International Herald Tribune, 4 July 1991, at http://www.iht.com/articles/1991/07/04/ford.php

European best practice in transport - the German example: why is car ownership higher in Germany than in the UK? UK Commission for Integrated Transport (2000), at http://cfit.independent.gov.uk/pubs/2000/ebpt/ebptgerman/04.htm

Desktop Study into Demand for Dairy Products, Section 2, "Factors affecting consumer demand for milk and dairy products", at

http://www.defra.gov.uk/foodfarm/food/industry/sectors/milk/pdf/agraceasreport.pdf

\section{DATA REQUIRED FOR Q1, EXEMPLAR 1}

Using the World Economic Outlook (WEO) database find the GDP for the UK, 1980-2009, at (i) current prices and (ii) constant prices, available at http://www.imf.org/external/pubs/ft/weo/2009/01/weodata/index.aspx .

Using the source at http://www.autoindustry.co.uk/statistics/sales/index find the UK new vehicle registrations (in units) for the years 1980-2006 


\section{PESTICIDE DATA}

Table 1 provides information on the impact of a $30 \%$ commodity tax on each unit of pesticide produced under different demand elasticity and incidence assumptions.

TABLE 1 PESTICIDE DATA

\begin{tabular}{|c|c|c|c|}
\hline Scenario & $\begin{array}{l}\text { Price Elasticity } \\
\text { of Demand }\end{array}$ & $\begin{array}{l}\text { Price } \\
\text { Increase \% }\end{array}$ & $\begin{array}{l}\text { Change in Sales Reveue } \\
\text { for UK producers (£m) }\end{array}$ \\
\hline Base Case (no tax) & $\mathbf{n} / \mathbf{a}$ & $0 \%$ & $\mathbf{n} / \mathbf{a}$ \\
\hline $\begin{array}{l}\text { Inelastic, } 30 \% \text { tax, } 30 \% \text { of tax absorbed } \\
\text { by manufacturers }\end{array}$ & -0.2 & $21 \%$ & 168 \\
\hline $\begin{array}{l}\text { Inelastic, } 30 \% \text { tax, } 15 \% \text { of tax absorbed } \\
\text { by manufacturers }\end{array}$ & -0.2 & $26 \%$ & 175 \\
\hline $\begin{array}{l}\text { Less inelastic, } 30 \% \text { tax, } 30 \% \text { of tax } \\
\text { absorbed by manufacturers }\end{array}$ & -0.5 & $21 \%$ & 159 \\
\hline $\begin{array}{l}\text { Less inelastic, } 30 \% \text { tax, } 15 \% \text { of tax } \\
\text { absorbed by manufacturers }\end{array}$ & -0.5 & $26 \%$ & 164 \\
\hline $\begin{array}{l}\text { Inelastic, } 100 \% \text { tax, } 30 \% \text { of tax } \\
\text { absorbed by manufacturers }\end{array}$ & -0.2 & $70 \%$ & 121 \\
\hline $\begin{array}{l}\text { Inelastic, } 100 \% \text { tax, } 15 \% \text { of tax absorbed } \\
\text { by manufacturers }\end{array}$ & -0.2 & $85 \%$ & 144 \\
\hline $\begin{array}{l}\text { Less inelastic, } 100 \% \text { tax, } 30 \% \text { of tax } \\
\text { absorbed by manufacturers }\end{array}$ & -0.5 & $70 \%$ & 103 \\
\hline Less inelastic, $100 \%$ tax, $15 \%$ of $\operatorname{tax}$ & -0.5 & $85 \%$ & 120 \\
\hline
\end{tabular}

absorbed by manufacturers

Source: Table derived from Design of a Tax or Charge Scheme for Pesticides, report by ECOTEC for Department of the Environment, Transport and the Regions, March 1999

GENERAL NOTE

Producers of pesticides are legally responsible for paying the tax. The primary users of pesticides are farmers and local councils. Although manufacturers of pesticides are responsible for the tax, they can pass on some of the tax burden to buyers. How much of the tax that can be passed on will depend on the price elasticity of demand. The incidence of tax refers to how the tax burden is shared between producers and buyers. 
Core Concepts

Applications

Response Required
Production, Costs and Revenue

Economics of Wind Power

Group Presentation

\section{SUBMIT PRESENTATION FILE ONE WEEK BEFORE PRESENTATION}

\section{Formal group presentations (20 MINUTES EACH)}

1 (a) Complete Table 2

(b) Are the $\mathrm{MC}$ and $\mathrm{AC}$ data consistent with the basic theory you met in the TEXT?

(c) Do the data in Table 2 depict a short-run or long-run scenario?

(d) Using the source, Wind Power Economics (EWEA, 2005), available at:

http://www.ewea.org/fileadmin/ewea documents/documents/publications/factsheets/factsheet economy2.pdf (and/or any other source you have found), identify the likely sources of economies of

scale in the production of wind power energy.

2 Identify the economic and environmental arguments FOR and AGAINST the use of wind power to generate electricity

\section{LEARNING OUTCOMES - AFTER THIS TASK STUDENTS WILL BE ABLE TO:}

- know the importance of the distinction between the short and long run in the analysis of production costs

- understand the determinants of unit costs in both the short-run and long-run

- be able to apply their knowledge of production costs to analyse specific industrial situations 


\section{EXEMPLAR 2}

\section{2 of 2}

\section{Notes for Task Leader:}

You may need to prompt the group to encourage discussion in the following areas:

Key concepts

Total costs and total sales revenue, marginal and average cost; marginal and average revenue; profit maximisation; short run and long run production costs; fixed and variable factors; fixed and variable costs; law of diminishing returns; economies and diseconomies of scale; U-shaped unit and marginal costs in short and long run.

\section{Learning resources}

TEXT

INTRANET

INTERNET
The firm's supply decision Short run production costs Long run production costs

Production Costs

\section{TEXT REFERENCE (essential) TEXT REFERENCE (essential) TEXT REFERENCE (essential)}

Lecturer's online presentation (optional)

Wind Power Economics, European Wind Energy Association (2005), available at http://www.ewea.org/fileadmin/ewea_documents/documents/publications/factsh eets/factsheet_economy2.pdf

"The cost of Wind Power", in Windletter, The American Wind Energy Association, May 2003, at http://www.awea.org/windletter/wl 03may.html 
The electricity produced by a wind turbine over one year is measured in kilowatt hours/year (kWh/year). The maximum yearly output of a wind turbine will depend upon the power producing capacity of the turbine (measured in kilowatts, $\mathrm{kW}$ ) and the number of hours/year at which the turbine operates at full capacity. The latter is clearly dependent upon wind conditions, with coastal and upland areas offering the best sites. The maximum yearly output of a wind turbine is given by:

\section{OUTPUT $(\mathrm{kWh} /$ year $)=$ TURBINE POWER $(\mathrm{kW}) *$ TIME $(\text { hours } / \text { year at full-load })^{1}$}

TABLE 2: WIND POWER OUTPUT and ESTIMATED COSTS per kWh

\begin{tabular}{|c|c|c|c|c|c|}
\hline $\begin{array}{c}\text { Wind } \\
\text { Strength }\end{array}$ & $\begin{array}{c}\text { TIME } \\
\text { Full-Load } \\
\text { Hours / year } \\
(1)\end{array}$ & $\begin{array}{c}\text { OUTPUT } \\
{[\mathrm{kWh} / \mathrm{year}]}\end{array}$ & $\begin{array}{c}\text { Average Cost } \\
{[\mathrm{c} € / \mathrm{kWh}]}\end{array}$ & $\begin{array}{c}\text { Total Cost } \\
{[\mathrm{c} €]}\end{array}$ & $\begin{array}{c}\text { Marginal Cost } \\
{[\mathrm{c} €]}\end{array}$ \\
\hline LOW & 1500 & $(2)$ & $(3)$ & & $(5)$ \\
\hline LOW & 1700 & & 7.6 & & \\
\hline MEDIUM & 1900 & & 6.0 & & \\
\hline MEDIUM & 2100 & & 6.0 & & \\
\hline MEDIUM & 2300 & & 5.6 & & \\
\hline HIGH & 2500 & & 5.2 & & \\
\hline HIGH & 2700 & & 4.9 & & \\
\hline HIGH & 2900 & & 4.7 & & \\
\hline
\end{tabular}

Source: Data in Column (3) derived from European Wind Energy Association (2005), Wind Power Economics, Fig. 1, available at

http://www.ewea.org/fileadmin/ewea_documents/documents/publications/factsheets/factsheet_economy2.pdf Also available from the module WebCT

NOTE: Turbine capacity $=1,000 \mathrm{~kW}$; $\mathrm{c} €=$ Euro cents; Average Cost data in Column 3 assumes that capital costs and O\&M costs are discounted at 7.5\% discount rate [see discussion in above publication re. Figs. $1 \& 2]$.

${ }^{1}$ The definition of $\mathrm{kWh}$ is available from $\underline{\mathrm{http}: / / \mathrm{www} . g c s e . c o m / e n e r g y / \mathrm{kWh} . \mathrm{htm}}$ 


\section{EXEMPLAR 3}

Core Concepts

Applications

Response Required
Perfect Competition and Monopoly

Competition Policy, Regulatory Bodies, Consumer Council, Transport and Energy

Team Quiz

\section{'UNIVERSITY CHALLENGE’ QUIZ}

\section{Questions will focus on the following}

1 The perfectly competitive industry in the short and long run

2 The profit maximising monopolist in the short and long run

3 The price discriminating monopolist

$4 \quad$ Natural monopoly

5 The Internet sources listed below

\section{LEARNING OUTCOMES - AFTER THIS TASK STUDENTS WILL BE ABLE TO:}

$\circ$ Distinguish between normal and supernormal profits

$\circ$ derive and illustrate the revenue and cost conditions that generate maximum profit/minimum losses for PC firms and Monopolists in the SR and LR

- assess the outcome of competitive structure (and lack of it ) for consumers, producers and society as a while

○ understand the role of consumer groups and regulating bodies in controlling the market power of monopolists

$\circ$ apply their knowledge of market structure to specific industries

\section{Notes for Task Leader:}

You may need to prompt the group to encourage discussion in the following areas:

Key concepts

Total, average and marginal revenue concepts; profit maximisation; normal and supernormal profits; perfect competition (PC); short and long run equilibrium of firm and industry in PC; profit maximisation under monopoly; discriminating monopoly and natural monopolies. 


\section{EXEMPLAR 3}

\section{2 of 2}

\section{Learning Resources}

TEXT Revenue, profit, perfect competition, monopoly

TEXT REFERENCE (essential)

INTRANET Perfect competition, Monopoly Lecturer's online presentation (optional)

\section{INTERNET}

Phoenix Gas [ sole supplier of natural gas in Northern Ireland]

http://news.bbc.co.uk/2/hi/uk_news/northern_ireland/2773243.stm

http://news.bbc.co.uk/2/hi/uk_news/northern_ireland/3561873.stm

http://news.bbc.co.uk/2/hi/uk_news/northern_ireland $/ 3525416 . \mathrm{stm}$

http://news.bbc.co.uk/2/hi/uk_news/northern_ireland $/ 3602786 . \mathrm{stm}$

http://news.bbc.co.uk/2/hi/uk_news/northern_ireland/4626912.stm

http://www.phoenix-natural-gas.com/

http://www.consumercouncil.org.uk/publications/?id=110

Translink Services [sole supplier of bus and rail services in Northern Ireland]

http://www.translink.co.uk/enterprisefares.asp

http://www.consumercouncil.org.uk/publications/?id=81 This paper relates to 'transport poverty'

\section{Questions involving OHP facility. See "Competition \& Monopoly" at the following}

link: http://www.economicsnetwork.ac.uk/projects/mini/forsythe pbl.htm

- All OHP questions will involve partially completed diagrams (i.e. no labels and missing schedules) relating to the theory of the firm under varying competitive conditions.

- Diagrams may contain deliberate errors, such as wrongly positioned equilibria, wrongly labelled schedules ....... etc.

- Teams winning the 'starter' question for a particular diagram have an opportunity to earn additional points by completing the diagram and correcting any deliberate errors in the process. 


\section{EXEMPLAR 3}

\section{General Questions (intended for rapid $Q \& A$ session, not using $O H P$ facility)}

1. What is the profit maximising condition for a PC firm?

2. List the conditions necessary for PC

3. What is 'normal' profit?

4. Why is the distinction between firm and industry important in PC?

5. Define marginal revenue (MR)

6. Define marginal cost (MC)

7. Average revenue (AR) always equals .........

8. In PC, a firm is a price

9. What is the significance of $\mathrm{AR}>\mathrm{AC}$ ?

10. Why does MR fall as monopolist raises output?

11. In PC, $\mathrm{P} \ldots \ldots . \mathrm{MC}$, but in monopoly, $\mathrm{P}$...... MC

12. If $\mathrm{AC}<\mathrm{AR}$, what happens in $\mathrm{PC}$ ?

13. If $\mathrm{AC}<\mathrm{AR}$, What happens in Monopoly?

14. In Monopoly, the distinction between the LR \& SR is

15. In the LR a PC firm will earn .......... ?

16. In the LR a monopolist will earn .......?

17. Why are normal profits treated as a cost?

18. In PC why will the firm NOT sell BELOW the market price?

19. Name the market: $\mathrm{AR}>\mathrm{AC} ; \mathrm{P}=\mathrm{AR} ; \mathrm{MC}=\mathrm{MR} ; \mathrm{MC}=\mathrm{P}$

20. What type of firm can exercise price discrimination?

21. What conditions are necessary for price discrimination?

22. Identify THREE monopoly services within NI

23. Can MR \& AR schedules ever coincide in monopoly?

24. Why does MR normally lie below AR in monopoly?

25. Why does $\mathrm{MR}=\mathrm{AR}$ in $\mathrm{PC}$ ?

26. How does a 'natural monopoly' arise?

27. What does OFREG stand for?

28. In $\mathrm{PC}$, if $\mathrm{AC}<\mathrm{AR}$ what profits are being earned?

29. In $\mathrm{PC}$, if $\mathrm{AR}>\mathrm{AC}$, what will happen to market price?

30. Define the short run in a PC industry

31. In $\mathrm{PC}$, if $\mathrm{AC}<\mathrm{AR}$ what will happen to the industry supply curve?

32. In $P C$, if $A C>A R$ what will happen to the industry supply curve?

33. From consumer viewpoint, what makes $\mathrm{PC}$ attractive?

34. From a firm's viewpoint, what makes PC unattractive?

35. From efficiency viewpoint, what makes PC attractive?

\section{Questions based on Internet Sources ( $Q \& A$ session testing teams' research effort)}

36. What evidence is there of price discriminating behaviour in NIR?

37. What evidence that Pheonix Gas exercises monopoly power?

38. Identify THREE ways that have been used to control Pheonix Gas

39. What stance does the NI Consumer Council take in relation to Pheonix Gas?

40. How does Pheonix Gas project itself?

41. What case does Phoenix Gas present for raising prices?

42. What stance does the NI Consumer Council take in relation to Translink?

43. The MC of a journey made by public transport is (more or less) than by car

44. What is the 'transport trap'?

45. What are the advantages of a 'hail \& ride' bus service?

46. Re. Phoenix Gas, what does 'revenue recovery period' mean?

47. Why should extending the RRP help stabilise gas prices?

48. How many increases in gas prices occurred between 1996-2002? 


\author{
Core Concepts \\ Applications \\ Response Required
}

Comparative Advantage, Trade Policy \&Tariffs, Exchange Rates Somalia, UK, Germany, Ethiopia, Written Report OR Group Presentation (groups are free to choose response format)

1 Explain how the theory of comparative advantage could account for the data in Table 1.

2 Explain why it is necessary to distinguish between :

(i) differences in factor endowments, and

(ii) market structure when accounting for the data in Tables 2 and 3.

3 (a) Using Tables 4-6 calculate Israel's terms of trade for 2004, 2005, and 2006.

(b) Which price movements most influenced its terms of trade since 2004?

4 Identify the arguments for tariff protection implied in, "Ethiopia on the track of joining WTO", Ethiopian Reporter, Saturday 8/10/2005.

What are the arguments against Ethiopia using tariffs as a policy instrument?

5(a) Outline the protectionist measures associated with the rise of economic nationalism highlighted in the 2009 Financial Times article, "Rising protectionism", Financial Times, Friday 3/2/2009

(b) Explain the main arguments against the use of protective trade measures?

6(a) Using supply and demand diagrams explain (i) how the equilibrium value of the pound in terms of euros is determined in the foreign exchange market, and (ii) why a rise in UK interest rates relative to eurozone rates could strengthen the pound against the euro.

6(b) Evaluate the view that a fall in the value of the pound benefits the UK economy, referring to the Daily Telegraph (2008) and Financial Times (2008) articles below.

\section{LEARNING OUTCOMES - AFTER THIS TASK STUDENTS WILL BE ABLE TO:}

- Apply and appraise the principle of comparative advantage using real data

Evaluate the use of restrictive trade policies, including tariffs

- Determine and discuss the terms of trade using real data

- Use basic supply and demand analyses to analyse the foreign exchange market

- Evaluate the impact of a depreciating pound on the UK economy 
Notes for Task Leader:

You may need to prompt the group to encourage discussion in the following areas:

Key concepts

Absolute and comparative advantage; terms of trade; trade policy, including tariffs; exchange rate determination; impact of a depreciating / appreciating currency on export and import prices - here you should also consider the relevance of price elasticities of demand for exports and imports.

\section{Learning resources}

TEXT

INTRANET

INTERNET
Relevant sections /pages

Appropriate resources

\section{TEXT REFERENCE (essential)}

Lecturer's online presentation (optional)

http://en.ethiopianreporter.com/

http://www.telegraph.co.uk/

http://www.ft.com/home/uk

http://www.intracen.org/countries/ (International Trade centre)

http://unstats.un.org/unsd/trade/imts/analyticaltradetables.htm (UN statistics division)

The following are relevant for Question $6 \mathrm{~b}$

"No help in sight for the falling pound", Daily Telegraph, 15/12/2008

"London and tourists enjoy weak pound", Financial Times, 19/12/2008

"Ground down by the pound", Financial Times, 25/11/2008 


\begin{tabular}{|c|c|c|c|c|c|}
\hline \multirow[b]{2}{*}{ Product } & \multicolumn{2}{|c|}{ Ranking $^{1}$} & \multirow[b]{2}{*}{ Product } & \multicolumn{2}{|c|}{ Ranking $^{1}$} \\
\hline & $\begin{array}{l}\text { Export } \\
\text { Rank }\end{array}$ & $\begin{array}{l}\text { Import } \\
\text { Rank }^{2}\end{array}$ & & $\begin{array}{l}\text { Export } \\
\text { Rank }^{2}\end{array}$ & $\begin{array}{l}\text { Import } \\
\text { Rank }\end{array}$ \\
\hline Live Sheep \& Goats & 1 & n.a. & Sugar Cane or Sugar Beet & n.a & 1 \\
\hline Wood Charcoal & 2 & n.a & Vegetable products & n.a & 2 \\
\hline Animal Products & 3 & n.a & Cigars \& Cigarettes & n.a & 3 \\
\hline Wood Pulp & 4 & n.a & Rice & n.a & 4 \\
\hline Live Bovine Animals & 5 & n.a & Wheat or Meslin Flour & n.a & 5 \\
\hline
\end{tabular}

Source: International Trade Centre (ITC)

Notes: (1) ranking is based on the value of exports and imports in US \$million.

(2) n.a. for export/import rank means product is not exported/imported

TABLE 2 UNITED KINGDOM

TRADED GOODS 2004 (US £billion)

\begin{tabular}{lclccc}
\hline Product & & & & & \\
& $\begin{array}{l}\text { Export } \\
\text { Rank }\end{array}$ & $\begin{array}{l}\text { Export } \\
\text { Value }\end{array}$ & $\begin{array}{c}\text { Import } \\
\text { Rank }\end{array}$ & $\begin{array}{c}\text { Import } \\
\text { Value }\end{array}$ & $\begin{array}{c}\text { Net } \\
\text { Exports }\end{array}$ \\
\hline Cars & 1 & 18.6 & 1 & 30.9 & -12.3 \\
Medication Mixtures & 2 & 16.2 & 4 & 11.0 & +5.2 \\
Crude Petroleum Oils & 3 & 15.1 & 5 & 9.7 & +5.4 \\
Turbo Jets \& Other Gas Turbines & 4 & 12.2 & 10 & 6.7 & +5.5 \\
Automatic Data Processing machines & 5 & 9.5 & 2 & 15.2 & -5.7 \\
Motor Vehicle Parts & 10 & 6.9 & 3 & 11.5 & -4.6 \\
\hline
\end{tabular}

Source: International Trade Centre (ITC)

Notes: (1) net export value is plus when value of exports exceed the value of imports and minus when value of exports is less than the value of imports. All values in terms of US \$billion.

TABLE 3

TRADED GOODS 2004 (US \$billion)

\begin{tabular}{lccccc}
\hline Product & $\begin{array}{c}\text { Export } \\
\text { Rank }^{1}\end{array}$ & $\begin{array}{c}\text { Export } \\
\text { Value }^{1}\end{array}$ & $\begin{array}{c}\text { Import } \\
\text { Rank }\end{array}$ & $\begin{array}{c}\text { Import } \\
\text { Value }\end{array}$ & $\begin{array}{c}\text { Net } \\
\text { Exports }^{2}\end{array}$ \\
\hline Cars & 1 & 91.5 & 1 & 32.8 & +58.7 \\
Motor Vehicle Parts & 2 & 24.9 & 5 & 15.0 & +9.9 \\
Medication Mixtures & 3 & 16.2 & 9 & 8.5 & +7.7 \\
Automatic Data Processing machines & 4 & 12.5 & 3 & 17.8 & -5.3 \\
Aircraft & 5 & 11.5 & 10 & 8.5 & +3.0 \\
Crude Petroleum Oils & n.a & n.a & 2 & 23.3 & -23.3 \\
Petroleum Gasses & 31 & 3.6 & 4 & 17.0 & -13.4 \\
\hline
\end{tabular}

Source: International Trade Centre (ITC)

Notes: (1) n.a. for export rank and export value means product is not exported.

(2) net export value is plus when value of exports exceed the value of imports and minus when value of exports is less than the value of imports. All values in terms of US \$billion. 
Table 4 The relative value of Israeli imports, and exports, as a percentage of the total in the year 2000

\begin{tabular}{|c|c|c|c|c|c|c|c|}
\hline \multicolumn{4}{|c|}{ imports: } & \multicolumn{4}{|l|}{ exports: } \\
\hline fuels & $\begin{array}{c}\text { other } \\
\text { raw } \\
\text { materials }\end{array}$ & $\begin{array}{l}\text { other } \\
\text { imports }\end{array}$ & $\begin{array}{l}\text { total } \\
\text { imports }\end{array}$ & agriculture & diamonds & $\begin{array}{c}\text { other } \\
\text { manufactures* }\end{array}$ & $\begin{array}{l}\text { total } \\
\text { exports }\end{array}$ \\
\hline 15.1 & 51.6 & 33.3 & 100 & 2.4 & 37.6 & 60 & 100 \\
\hline
\end{tabular}

* other manufactures include low-, medium-, and high-technology manufactures (excluding diamonds)

Table 5 Israeli import price indices $(2000=100)$

\begin{tabular}{ccccc}
\hline & fuels & $\begin{array}{c}\text { other raw } \\
\text { materials }\end{array}$ & $\begin{array}{c}\text { other } \\
\text { imports }\end{array}$ & $\begin{array}{c}\text { total } \\
\text { imports }\end{array}$ \\
\hline 2004 & 128.2 & 113.4 & 107.6 & 111.8 \\
2005 & 176.2 & 125.4 & 111.0 & 120.0 \\
2006 & 208.0 & 135.9 & 126.2 & 127.1 \\
\hline
\end{tabular}

Table 6 Israeli export price indices $(2000=100)$

\begin{tabular}{ccccccc}
\hline & agriculture & diamonds & $\begin{array}{c}\text { low technology } \\
\text { manufactures }\end{array}$ & $\begin{array}{c}\text { medium technology } \\
\text { manufactures }\end{array}$ & $\begin{array}{c}\text { high technology } \\
\text { manufactures }\end{array}$ & $\begin{array}{c}\text { total } \\
\text { exports }\end{array}$ \\
\hline 2004 & 125.2 & 113.0 & 106.1 & 111.9 & 98.0 & 107.4 \\
2005 & 124.1 & 134.4 & 110.0 & 126.8 & 95.3 & 116.2 \\
2006 & 124.2 & 143.6 & 113.7 & 139.0 & 95.1 & 121.1 \\
\hline
\end{tabular}

Note: A 'base year' price is valued as 100 (the base year here is the year 2000). Price indices for other years show how a price differs from the base year. For example the price index for diamonds in 2004 was 113.0, which means that the price of exported diamonds was 13\% higher in 2004 than in 2000. In 2006 it was $43.6 \%$ higher than in 2000 . Comparisons with non-base year prices can also be made, by calculating the relevant percentage. For example, the price rose between 2004 and 2006 by 27\%, since $(143.6 / 113.0)$ $\mathrm{x} 100=127$. 